\title{
Angelika Kellner* \\ Time Is Running. Ancient Greek Chronography and the Ancient Near East
}

https://doi.org/10.1515/jah-2019-0027

Abstract: The article explores the question whether there was a possible dialogue between ancient Greek and Mesopotamian chronography. This is an interesting albeit challenging subject due to the fragmentary preservation of the Greek texts. The idea that cuneiform tablets might have influenced the development of the genre in Greece lingers in the background without having been the subject of detailed discussion. Notably the Neo-Assyrian limmu list has been suggested as a possible blueprint for the Athenian archon list. In order to examine this topic further, a thorough analysis of ancient Greek chronography starting in the second half of the fifth century $\mathrm{BC}$, when eponymous dates in various literary compositions begin to appear, is required. A close examination of the fragmentary evidence shows how difficult it is to trace the supposed annalistic style in the local histories of Athens (Atthides). In the Neo-Assyrian Empire, the eponymous limmu officials served as the chronological backbone, but there remains a huge time gap between the seventh century cuneiform manuscripts and the Athenian archon list from the fifth century. A comparison of the Neo-Assyrian Eponymous Chronicles with the preserved Greek chronographic traditions in Eusebius' chronicle (fourth century AD) shows that the similarity is mainly confined to an abbreviated style, as the entries clearly point to the different cultural and political settings. Apart from the Neo-Assyrian sources, the Neo- and Late-Babylonian chronicles deserve further attention in the present inquiry. Looking for a connection with ancient Greek chronography in the fifth century, the lack of wholly preserved texts on both sides in the corresponding time constitutes an unsurmountable obstacle. Presenting and scrutinising the textual evidence both for ancient Greek and for Mesopotamian chronography enables an improved understanding of similarities and differences alike. To exemplify this point, Greek and Akkadian temple histories serve as test cases.

Key words: ancient Greek chronography, Greek historiography, Assyrian and Babylonian chronicles

*Corresponding author: Angelika Kellner, Institute of Ancient History and Ancient Near Eastern Studies, University of Innsbruck, Langer Weg 11, 6020 Innsbruck, Austria,

E-Mail: angelika.kellner@uibk.ac.at

ə Open Access. (๑) 2021 Angelika Kellner, published by De Gruyter. This work is licensed under the Creative Commons Attribution 4.0 International License. 
Especially since the ground-breaking work by Burkert ${ }^{1}$ an effort has been made to bridge the gaps between the various specialised disciplines for studying the Mediterranean Asia Minor and Mesopotamia in the early Iron Age. Recent contributions have tried to emphasise that the Mediterranean world was one in motion and that the different peoples were in constant contact with each other. ${ }^{2}$ Such an interaction is probably most visible in the archaeological record, if one thinks of the wide geographical distribution of Greek pottery in the Mediterranean on the one hand and of the "Oriental" imports in "Greek" areas on the other. ${ }^{3}$ Probably more open for discussion are the influences on various Greek texts, e.g. the subject of law, historiography, poetry and myth, as the huge amount of secondary literature nowadays shows. ${ }^{4}$ Concerning the text genre in question here, chronography, scholars have only passingly commented on the possibility that especially the Assyrian eponymous limmu list and Assyrian/Babylonian chronicles might have influenced the development of similar writings and concepts in Greece, ${ }^{5}$ but to the best of my knowledge never fully explored this question in detail. ${ }^{6}$ The assumption of a connection lingers in the background based on the knowledge of eponymous dating both in cuneiform and Greek texts. However, the mere existence of eponymous dating systems in Greece and Mesopotamia is in my opinion not enough to argue for a transmission or influence. Hence, a thorough analysis and discussion of the chronographic texts is lacking in this regard, but which the present paper seeks to provide. One major relevant contribution is the book by Burgess and Kulikowski with the telling subtitle A Historical Introduction to the Chronicle Genre from its Origins to the High Middle Ages. One of their crucial

1 Burkert (1984); (1992). It has been noted, though, that Burkert's work has generally had little impact in Assyriology: see Márquez Rowe (2018). All dates in this paper are BC unless otherwise noted.

2 For methodological concepts of cultural contacts, see Ulf (2014a; 2014b).

3 For the sake of brevity, the terms "Greek" and "Oriental" have been applied here. However, I would like to point out that the term "Greek" is not without major methodological problems for the Archaic period (Hall 1997). Similar objections apply to the concept of a Near East, as it already shows a strictly Western perspective (Said 1978; Van Dongen 2014). Hence, both terms have been marked with quotation marks in the text above.

4 As the secondary literature on this topic is vast, I would like to refer to a limited selection of comparatively recent contributions. For law texts: Rollinger (2004); Raaflaub (2011); Westbrook (2015). Generally for literary texts: Haubold (2013). For historiographical texts: Lanfranchi (2000a); Gufler and Madreiter (2015); Rollinger (2017); Finn (2019). For poetry and myth: West (1997); Dalley (1998); Lang (2008); Rollinger (2014a); West (2018).

5 E.g. Millard (1994), 1; Chaniotis (1998), 4; Panchenko (2000), 64; Möller (2001), 253-254.

6 Hanell's (1946), 79-94 approach to date the beginnings of ancient Greek chronography back in the eighth/seventh century and to compare it directly with the "contemporary" cuneiform evidence has to be considered outdated. 
observations regards the insight that a new definition of the term "chronicle" depicts an academic necessity, as different scholarly disciplines, i.e. Classicists, Assyriologists and Medievalists, employ diverging notions. By providing a new classification for chronicles, they have enabled the study of chronicles both in cuneiform and Greek literature. ${ }^{7}$

What I would like to investigate in the present paper is the question of a possible dialogue between ancient Greek and cuneiform chronography from the perspective of the Greek evidence. In order to avoid a superficial and not very useful comparison between eponymous dating, I will briefly contextualise, summarise and discuss the genre of chronography in Greek and cuneiform sources. Thus, the paper aims to contribute to our knowledge of first-millennium ancient literature against the background of culture contact studies. In general, the highly fragmentary state of the Greek texts poses a serious challenge when trying to draw definite conclusions about content and form. Newly developed methodological concepts make it necessary to scrutinise the state of knowledge about this genre, which fundamentally rests on Jacoby's ${ }^{8}$ seminal work. The paper will offer a discussion of the most essential evidence in order to gain an impression of ancient Greek chronography, foremost the Athenian archon list and the written histories of Athens (Atthides). In a next step, according to the seemingly widespread assumption that ancient Greek chronography was influenced by similar writings from the Ancient Near East, these cuneiform texts will be discussed. In particular, this concerns the question whether the Neo-Assyrian limmu list might have served as a blueprint for the Athenian archon list. Even though the poor preservation of ancient Greek chronography impedes a direct comparison, my inquiry will attempt to consider parallels with Neo-Assyrian and Babylonian chronicles by confronting them.

Let us first have a look at the definitions of the chronography genre on the one hand for classical sources and on the other for cuneiform literature. ${ }^{9}$ Möller

7 Burgess and Kulikowski (2013), 1-62. They offer a short summary of their new definition of chronicles at p. 59: "We use this term to describe any historical work that meets the following criteria: it is brief, annalistic (i.e. recounts a year-by-year chronology), concerned in some way with chronology, be that annalistic (year-by-year) of absolute, paratactic in its narrative, and extensive in its chronological coverage (i.e. usually aspiring to cover hundreds or thousands of years rather than individual years or decades)."

8 Jacoby wrote his dissertation (1902b) as well as his habilitation about chronographic texts. In the former Jacoby dealt with Apollodorus' chronicle and in the latter he studied the Marm. Par. (1904a). For Jacoby's achievements specifically for ancient Greek chronography, see Möller (2006).

9 The assignment to a certain genre influences the modern perception of a composition, as the research history of the Tummal Chronicle clearly shows. The text tells the story of the Ninlil sanctuary with reference to various kings and has hitherto been recognised as representative of the chronographic genre. In a recent study Michalowski (2006) has, however, concluded that the com- 
provides a very brief but useful definition for the Greek texts: "Chronography [...] describes a record of historical events precisely dated by reference to an absolute chronological system." ${ }^{10}$ In contrast, Grayson could directly refer to the long tradition of king lists and chronicles in Mesopotamia: "By definition the word chronographic denotes documents which are composed along essentially chronological lines. This is certainly a characteristic of ancient Mesopotamian king lists and chronicles which makes them a distinct entity." ${ }^{" 11}$ A comparison of these two statements already hints at crucial differences in the ancient texts. Möller's statement is furthermore linked to the poor preservation of the Greek texts, which will be the main subject of the next section.

\section{Greek chronography and the Athenian Archon List $^{12}$}

In the second half of the fifth century lists of eponymous secular and sacred officials which reached back into the Archaic period (c. 800-500) were published in various Greek cities. This is usually understood to mark the beginning of ancient Greek chronography. ${ }^{13}$ When Thucydides (2.2.1) tried to precisely date the outbreak of the Peloponnesian War (431) he used amongst others the eponymous dates of three Greek cities. He refers to the Spartan ephor Aenesias, the Athenian archon Pythodoros as well as to the $48^{\text {th }}$ year of the priestess of Hera Chrysis at Argos. Additionally, Thucydides states that Pythodoros was in office for a further four months. ${ }^{14}$ This text passage allows the valuable insight that at the time Thu-

position belongs to the environment of Old Babylonian schools. In his opinion, the text depicts a pedagogical piece filled with irony and lacks any serious chronographic purpose.

10 Möller (2004b), 170.

11 Grayson (1975), 4.

12 Sections I and II are partially based on my PhD thesis (Kellner 2019).

13 The most comprehensive study of ancient Greek chronography is still Mosshammer (1979). More recent and detail-oriented studies include: Möller (1996); Panchenko (2000); Taylor (2000); Kõiv (2001); Möller (2001; 2004a; 2004b; 2005; 2006); Christesen (2007); Feeney (2007); Kokkinos (2009a; 2009b; 2013). I argue that before the chronographic conventions of the Hellenistic period generation counting was the predominant if not the only available dating method besides synchronisms in the Archaic period. These "pre-chronographic" traditions are in my opinion not suited to discuss the question of a possible Near Eastern influence on Greek chronography.

14 The additional information probably sought to sort out any confusion which might have occurred due to the different starting moment of the various offices. All the manuscripts contain the

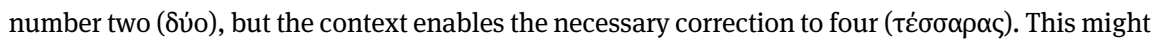


cydides was writing he could access information on who held the eponymous office in the mentioned cities in this specific year. The reasons for publishing lists of sacred and secular officials - such as the Athenian archons, the priestesses at Argos or even the Olympic victors ${ }^{15}$ - in the second half of the fifth century are complex and manifold. ${ }^{16}$ An increased use of the alphabet in general, ${ }^{17}$ the emergence of historiography, as well as an interest in the past from a political and scholarly point of view contributed to this development. Merely explaining these lists as products of antiquarian concern as a scholarly exercise does not do the ancient circumstances justice. One has to be aware of the contemporary context and at times even political intent which played an important role in the creation of these lists. ${ }^{18}$ I would like to refer to two telling examples that can shed light on this specific background. Firstly, placing an inscription on the Athenian agora in the fifth century with the names of the past archons clearly shows the continuity and antiquity of the Athenian political office and community. ${ }^{19}$ Secondly, when Elis had to fear the loss of the prestigious sanctuary Olympia, the context in the Elean War might have formed one reason for compiling the first list of Olympic victors around $400 .{ }^{20}$ One can imagine a reasoning where showing the long-established leadership of Elis at the Olympic Games should strengthen the contested claim in a difficult political situation. ${ }^{21}$

Highly fragmentary preservation makes ancient Greek chronography a difficult subject. All of the fifth-century chronographic texts owe their survival to quotations by later authors, thus introducing serious methodological challenges. Hippias' Olympionikon Anagraphe is only attested by Plutarch (second century AD; BNJ 6 F2 ap. Plut. Num. 1.4), but no single explicitly ascribed fragment has been transmitted. ${ }^{22}$ Therefore, it remains contested, for example, who introduced the

easily be explained with a confusion of the number four $(\bar{\delta})$ for two (סv́o), as Gomme (1962), 2 has argued. In another passage Thuc. 5.20.2-3 actually criticises the practice of eponymous dates. Taylor (2000), 227-232 suggests that his criticism was primarily targeting time intervals, which would make sense regarding the duration of the Peloponnesian War.

15 It is generally assumed that Hippias compiled the list of Olympic victors after Thuc., as he nowhere refers to it in his History.

16 For the beginning of ancient Greek chronography and the chronographic lists in the fifth century, see Taylor (2000).

17 For the situation in fifth century Athens, see Thomas (1989).

18 See e.g. Gehrke's (2014) concept of intentional history.

19 Taylor (2000), 51. Rotstein (2016), 15 uses a similar argument for the Marm. Par. in the third century. A symbolic rather than practical function of the Athenian archon list seems to be further implied by the marginal letter height of only $1.2 \mathrm{~cm}$.

20 For a precise reconstruction and date of the conflict between Elis and Sparta, see Unz (1986).

21 Christesen (2007), 57. 
table form into chronography. Various ancient authors have been credited with this innovation, among them Timaios ${ }^{23}$ (third century), Castor of Rhodes ${ }^{24}$ (first century) and the Christian chronicler Eusebius ${ }^{25}$ (third/fourth century AD). Similar difficulties are visible in the various attributions for introducing Olympiad dating, such as to Aristotle ${ }^{26}$ (fourth century), Timaios ${ }^{27}$ (third century) or Eratosthenes $^{28}$ (third century). Eusebius' chronicle ${ }^{29}$ is of particular importance for the chronology of classical antiquity, but has not - characteristically for ancient Greek chronography - survived in its original Greek version. Scholars mainly rely on the Latin transcription by Jerome ${ }^{30}$ (fourth century AD) and an Armenian manuscript tradition ${ }^{31}$ (fifth century AD). The chronicle comprised a chronological time frame from Abraham's birth until the year convertible into AD $325^{32}$ and refers to many important events as well as persons of classical antiquity. Altogether, Eusebius' chronicle constitutes a valuable source, as it collects otherwise lost chronographic works.

Regarding the poor preservation of ancient Greek chronography, the seminal paper by Brunt ${ }^{33}$ should serve as a plea for caution in the question whether fragments can indeed provide a reliable impression of a whole work. The present paper follows an according approach which at times disagrees with the more optimistic opinio communis. Another challenge when dealing with chronographic texts is the fact that in many cases the sum of the reign lengths for various dynas-

22 One could, of course, argue that the Olympic victor list in Euseb. (fourth century AD) ultimately builds on Hippias' work, but this is not explicitly stated. Euseb.s' Olympionikai can be found in various eds.: Karst (1911), 89-103; Christesen and Martirosova-Torlone (2006), 63-82 (App. 1), 83-93 (App. 2); Christesen (2007), 386-407 (App. 4.1).

23 Ball (1974), 42; Christesen (2007), 277; Baron (2013), 24-25.

24 Wachsmuth (1895), 139.

25 Helm (1924), 4; Helm (1956), XXXVIII; Mosshammer (1979), 37.

26 Christesen (2007), 171-172, 279, 287.

27 E.g. Mosshammer (1979), 87; Meister (1990), 132; Möller (2001), 270; Shaw (2003), 51, 54; Grafton and Williams (2006), 144.

28 Wachsmuth (1892), 3-13; FGrHist IIB, 707.

29 For the chronicle of Euseb. in general see: Mosshammer (1979), 29-83; Croke (1982); Adler (1992); Burgess (1999), 21-109; Burgess and Kulikowski (2013), 119-126.

30 Standard ed.: Helm (1956).

31 Standard ed., which only provides a German translation: Karst (1911). A new ed. is currently in preparation by Drost-Abgarjan (2006). A fifth-century AD date for the Armenian manuscript tradition seems to be the new scholarly consensus (Christesen and Martirosova-Torlone 2006, 45-48; Drost-Abgarjan 2006, 261), even though Karst ibid. XI-XII, LIV proposed a date in the eighth century AD.

32 Burgess (2002), 8.

33 Brunt (1980). 
ties does not add up, thus making an emendation necessary in the king list of Athens $^{34}$ and Tyros, ${ }^{35}$ for example. Even though a certain interference in the preserved sources seems required, some contributions have gone too far with speculative assumptions. ${ }^{36}$ Hence, modern text editions nowadays tend to ignore restorations which had previously been considered as established facts. ${ }^{37}$

\section{Eponymous archon dates and the Atthides}

Let us now turn to the evidence of the Athenian archon list and the practice of eponymous dating in particular. Herodotus, for example, does not use the Athenian archons in his digressions about the Peisistratids, ${ }^{38}$ which in theory - or at least for the modern reader - could have contributed to an easier chronological overview. Hence, I argue that Herodotus did not have access to a list containing the Athenian archons of the sixth century. ${ }^{39}$ Only for the date of the battle of Salamis does Herodotus (8.51.1) mention Kalliades as the Athenian archon. Scholars have considered this to be a "real" eponymous date, ${ }^{40}$ while others reject any chronological intention. ${ }^{41}$ According to the latter interpretation, Herodotus rather wants to refer to the overlap with the Attic time horizon, as he primarily employs the Persian kings for chronological orientation in his Histories. ${ }^{42}$ This specific characteristic is significant and strikingly underlines the lack of an overall eponymous dating system in Greece for the Archaic and early Classical period. ${ }^{43}$ As

\footnotetext{
34 Schwartz (1894); Jacoby (1902a).

35 Kokkinos (2013).
}

36 Tuplin (BNJ 691 F1) has pointed out a similar line of argument regarding the debate on the date ancient chronographers assigned to the fall of Sardis.

37 E.g. the new ed. of the Marm. Par. (third century) by Rotstein (2016). Jacoby (1904a), 13, 171 e.g. restored for the entry A42, where Croesus' defeat against Cyrus is noted, the year 541/0. However, a secure restoration is simply not possible.

38 For Hdt.'s chronology of the Peisistratids and the contrasting information in the Ath. pol., see Busolt (1895), 310-313; Hind (1974) (with an excellent overview of older contributions); Rhodes (1976); (1981), 191-199; Chambers (1990), 200-205.

39 E.g. Jacoby (1949), 350 no. 36; Mosshammer (1979), 88-89; Bichler (2004), 209-210 no. 8.

40 Strasburger (1956), 135; Ehrhardt (1992), 15.

41 E.g. Shaw (2003), 32.

42 Feeney (2007), 221-222 no. 35.

43 For the chronology of the Archaic period the Spartan king list plays a major role. Even though Hdt. 7.240, 8.131 includes a genealogy of the two Spartan kings, he does not explicitly use it for his chronology. Ancient authors supposedly relied upon the Spartan kings for chronological purposes (e.g. FGrHist 244 F61a, 62a), but the fragments themselves do not include a direct reference. That the 
already shown above, Thucydides (2.1.1) uses among others the Athenian archon to provide a universally recognisable date for the outbreak of the Peloponnesian War. Otherwise, Thucydides (5.20.2-3) applies a division in winter and summer seasons to tell the events connected to the Peloponnesian War. This is the state of evidence of the two great historiographers of the fifth century.

Table 1: Athenian archon list of the Athenian Agora according to IG I 1031

\begin{tabular}{|c|c|c|c|c|c|}
\hline \multirow{22}{*}{$\begin{array}{l}\text { Col. I } \\
\text { lacuna } 65 \text { vv. }\end{array}$} & & Col. II & & Col. III & Col. IV \\
\hline & & lacuna $2 \mathrm{vv}$. & & lacuna $2 \mathrm{vv}$. & lacuna $65 \mathrm{vv}$ \\
\hline & c & $-----v$ & 10 & $\mathrm{~K}-----$ & \\
\hline & & $-----v v$ & & $\Phi \alpha----$ & \\
\hline & & $-----v v$ & & $\mathrm{~T} \varepsilon----$ & \\
\hline & & $-----v$ & a. $548 / 7$ & 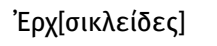 & \\
\hline & 5 & $-----\varsigma$ & & $\theta \varepsilon \sigma---$ & \\
\hline & & lacuna 13 vv. & 15 & $\Phi[0] \rho---$ & \\
\hline & b & {$[\ldots] \backslash---$} & & lacuna 18 vv. & \\
\hline & & [Kú] & & & \\
\hline & & {$[T \varepsilon] \lambda \varepsilon \kappa \lambda \varepsilon--$} & & & \\
\hline & a. $595 / 4$ & 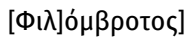 & & & \\
\hline & & lacuna $41 \mathrm{vv}$. & a & 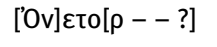 & \\
\hline & & & & [H]ıпாі́ $\alpha \varsigma$ & \\
\hline & & & & 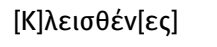 & \\
\hline & & & a. $524 / 3$ & {$[M] \iota \lambda \tau ı \alpha ́ \alpha \varepsilon \varepsilon \varsigma$} & \\
\hline & & & 20 & {$[K \alpha] \lambda \lambda ı \alpha ́ \delta \varepsilon \varsigma$} & \\
\hline & & & & 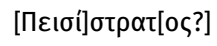 & \\
\hline & & & & lacuna 31 vv. & \\
\hline & & & d & 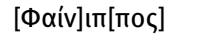 & \\
\hline & & & a. $489 / 8$ & 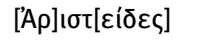 & \\
\hline & & & & vacat 0,04 & \\
\hline
\end{tabular}

Spartan king list already circulated in the fifth century is now proven by a newly identified fragment of Pherekydes: Fleischer (2019). 
Only later authors transmit a (partial) list of the Athenian archons for the Archaic and Classical period, above all Castor of Rhodes ${ }^{44}$ and Diodorus in the first century. ${ }^{45}$ Castor's list in turn only survives in Eusebius' chronicle. Already the Athenaion Politeia (3.1-3) from the fourth century presents the idea that the archon office developed gradually from kingship, lifelong archonship via ten-year archonship, finally to the annually appointed archons. Modern assessment sees this schematic concept as a chronographic construct, especially as far as the ten-year archonship is concerned. ${ }^{46}$ It has been suggested that additional time between the Attic kings and annual archons was thereby artificially inserted. This might have been necessary when the somehow fixed dates of the Attic kings were too far away from the (historical) annual archons. ${ }^{47}$

What makes the case of the Athenian archons so special for Greek chronography is the additional epigraphic evidence, which constitutes an extraordinary exception. While several other epigraphic sources contain lists of eponymous officials in the Greek world, they do not show the same importance for Greek chronology like the Athenian archon list. Excavations in the 1930s brought to light four fragments of an inscription ${ }^{48}$ which partially contain the names of Athenian archons. ${ }^{49}$ This inscription belongs paleographically to the last quarter of the fifth century and its epigraphic date is further supported, as from about 420 archon dates appear in degrees and public access to such a list is hence supposed..$^{50} \mathrm{~A}$ reliable reconstruction of the original size of the inscription remains difficult, as the estimations largely depend on the supposed content and the therefore necessary space. It remains, for example, disputed with which name the list started and if there was further additional information. Bradeen ${ }^{51}$ has reconstructed a stele with four columns and 65 names starting with the first annually appointed archon Kreon (in 683) ${ }^{52}$ and ending with Isarchos (424), but his reconstruction has to remain speculative. In addition, Dillon ${ }^{53}$ has recently addressed the general difficul-

44 FGrHist 250 F4 (ap. Euseb. Chron.: Karst 1911, 96-89).

45 Modern eds. provide a list: Samuel (1972), 195-237; Strothmann and Welwei (2004).

46 Busolt (1895), 135-136 no. 3; Hignett (1952), 42-43; Ledl (1973), 208-209, 249-250, 268; Taylor (2000), 45; Welwei (2017), 65.

47 Harding (2008), 84; Rhodes (2014), 33.

48 For these fragments: Bradeen (1963); Meiggs and Lewis (1969), 9-12 (= no. 6); IG I 1031.

49 The interpretation as an archon list was contested by Alexander (1958/9).

50 Ehrhardt (1992), 15; Christesen (2007), 102.

51 Bradeen (1963). Ball (1974), 110 has called attention to the fact that from the assumed first column not a single fragment is preserved, thus leaving the reconstruction with archons from the seventh century purely hypothetical.

52 Jacoby (FGrHist III B Suppl. 1, 14) already argued for the list's beginning with Kreon.

53 Dillon (2006). 
ties with the fragmentary archon names of the late sixth century and their respective reconstruction.

Returning to the question how the Athenian archons were used to date historical events, one has to deal with the fragmentary evidence of the fifth-century authors. The assessment thereof proves, by nature, to be less than clear. It is first necessary to demonstrate how Jacoby has established the opinio communis that Hellanikos arranged his Atthis annually by the Athenian archons. ${ }^{54}$ By creating a teleological scheme for the development of historiography and its subgenres in the fifth century, Jacoby managed to create a system for arraying the various fragmentary texts of the ancient Greek historians. He presented this idea in the famous article Über die Entwicklung der griechischen Historiographie und den Plan einer neuen Sammlung der Historikerfragmente in the year 1909, where he announced and explained the outline of his fragment collection. According to Jacoby, the historiographical genres developed step-by-step starting with mythography or genealogy (Hekataios), ethnography (Hekataios), chronography (Hellanikos), history (Herodotus and Thucydides) and finally horography (Hellanikos). In Jacoby's conception, each genre was constituted with all the crucial characteristics by its first author. Recent contributions have scrutinised this concept, which forms the guideline of Jacoby's fragment collection Die Fragmente der griechischen Historiker. ${ }^{55}$ This critique affects the assigned dates of various fifth-century authors and the question of which precise date should be applied instead. ${ }^{56}$ Of particular interest for the present paper is the discussion of how Hellanikos dated the events in his two compositions Hiereiai (The Priesteses of Hera at Argos) $)^{57}$ and Atthis. ${ }^{58}$ Jacoby considered Hellanikos' Hiereiai to be the first work of ancient Greek chronography with a compulsory annalistic form and a Panhellenic focus, ${ }^{59}$ as will be demonstrated further below in the discussion of the fragments. He deemed local history as the last subgenre of historiography in the fifth century and borrowed the term horography from later sources, which used the designa-

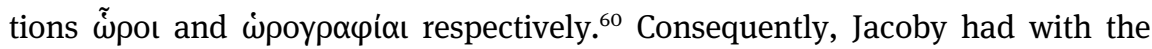
yearbooks a genre in mind that is well known only from the late Classical and

54 The following scholars accept Jacoby's interpretation: Ruschenbusch (2003); Harding (2007), 181-183; Fowler (2013), 685-687; Rhodes (2014), 19; BNJ 323a F25.

55 Recent contributions have discussed Jacoby's at times problematic and partially outdated concept: Marincola (1999; 2012); Porciani (2006); Schepens (2010); Funke (2014/5).

56 E.g. Fowler (1996).

57 For Hellanikos' Hiereiai: Pearson (1939), 225-231; Ambaglio (1980), 28-42, 56-57; Hornblower (1994), 223; Möller (2001); Christesen (2007), 95-99; Burgess and Kulikowski (2013), 82-83.

58 For Hellanikos' Atthis: BNJ/FGrHist 323a.

59 Jacoby (1909), 87-88.

60 Jacoby (1909), 109-110 (no. 2). E.g. Diod. Sic. 1.26.5; Censorinus, DN 19.6. 
especially the Hellenistic period, wherein the events are reported year by year. ${ }^{61}$ According to Jacoby ${ }^{62}$ both chronography and horography used an annalistic style but had a different focus, namely Panhellenic and local.

Turning to the preserved fragments of Hellanikos' Atthis, only two scholia of Aristophanes' play The Frogs directly support Jacoby's hypothesis. ${ }^{63}$ Both refer to Hellanikos' account of two events during the archonship of Antigenes (407/6, हैंع।

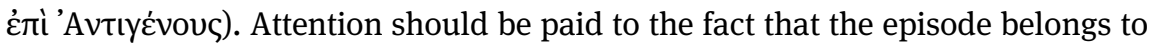
Hellanikos' contemporary time and that an inscription with a list of the Athenian archons was already publicly accessible. Lenardon has commented on the meagre evidence for a continuous annalistic form of Hellanikos' Atthis: "Perhaps what makes me most uneasy is that so much has been hypothesized on the basis of so little, i.e., these two fragments such as they are." ${ }^{44}$ Other scholars have agreed with this more sceptical view or left the question of a possible annalistic frame especially for the earlier parts open. ${ }^{65}$

Jacoby (FGrHist 324 F44) assumed that ancient authors applied the same formula for starting a year's entry in every Atthis, namely with the archon's name, his

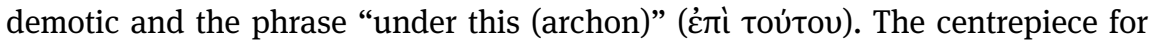
his assumption is based on the following fragment of Androtion (fourth century):

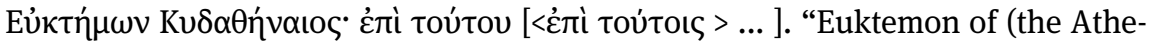
nian deme) Kydathenaion. Under this (archon) [408 BC ...]” (Greek text and English translation from BNJ 324 F44). Even though the formula is not preserved at all and depicts an emendation - albeit a plausible one - scholars generally assume it to have been consistently applied by Androtion and his successors. ${ }^{66}$ On the other hand, the various works with the title Atthis are not considered to be uniform. Therefore, one cannot assume a strict annalistic style from the title of an ancient work alone. ${ }^{67}$ Analogous to the development of Olympiad dating the scarce evidence makes it difficult to draw a complete picture of the development of Athenian archon dates in literature. Which side of the argumentation one chooses depends not only on the interpretation of the above-mentioned fragments but also

61 Funke (2014/5), 181.

62 Jacoby, FGrHist II D, 661-662.

63 FGrHist 323a F25 (ap. Schol. Ar. Ran. 694); FGrHist 323a F26 (ap. Schol. Ar. Ran. 720). See, however, the difficult textual situation with the first fragment, BNJ 323a F25.

64 Lenardon (1981), 66 no. 27.

65 E.g. Joyce (1990), 5-7; Toye (1995), 291-295; Pritchett (1996), 42-48; Sickinger (1999), 179; Bichler (2004), 209.

66 Jacoby (1949), 90-91; Toye (1995), 294; Joyce (1999), 3-4; Rhodes (2014), 18-19.

67 Marincola (1999), 282 no. 5, 312-312; Burgess and Kulikowski (2013), 81. 
on one's personal opinion about the historiographical and chronographic environment.

Assessing Hellanikos' dating method in his Atthis is also influenced by one's reconstruction of his other work Hiereiai. Dionysius of Halicarnassus (Ant. Rom. 1.72.2) provides the following valuable quote, when he writes about Rome's differ-

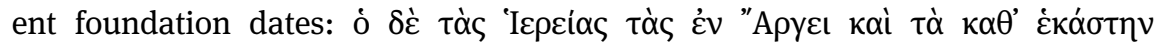

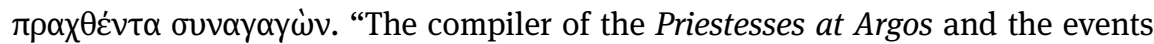
during the tenure of each of them [...]" (Greek text and English translation from BNJ 4 F84). Additionally, Dionysius (Ant. Rom. 1.22.3 = BNJ 4 F79b) writes in another passage that Hellanikos dates the emigration of the Sicels in the third generation before the Trojan War in the $26^{\text {th }}$ year of the Hera priestess Alcyone. Thus, Hellanikos did not focus on the history of Argos, but rather considered events from the Panhellenic world, as other fragments clearly show. Curiously enough, Hellanikos chose the priestesses of Hera at Argos as a chronological frame for his work. This has been interpreted as a conscious choice during the Peloponnesian War, as Argos remained politically neutral until $421 .^{68}$ In the preserved transmission no other author employed the priestesses to create a chronological system for Argos' or Greece's history. It remains a unique choice by Hellanikos. ${ }^{69}$ There exists only one possible exception, the Anagraphe Sikyonia ${ }^{70}$ (about 400), which might have provided a list of priestesses of Hera at Argos alongside poets and musicians. As there are only two fragments known, the text remains for the greater part elusive. Later chronographers did not transmit a list of the priestesses, probably because they did not regard this list to be important for chronology. ${ }^{71}$

As already mentioned above, Jacoby ${ }^{72}$ interpreted Hellanikos' Hiereiai as the first universal chronicle and saw in it the first work of ancient Greek chronography. According to Jacoby, Hellanikos assigned for each event the year of a priestess and thus assumed a strict annalistic form. Looking at the fragments themselves, only two provide direct evidence for this interpretation. Hellanikos' Hiereiai is mainly quoted by the sixth-century AD lexicographer Stephanus of Byzantium, who does not transmit a single eponymous date. Jacoby had, therefore, to assume that Stephanus only quoted Hellanikos for the information of a historical event without the eponymous date, like for example the foundation of Naxos in Sicily (BNJ 4 F82 ap.

68 Ambaglio (1980), 40-41; Möller (2001), 255.

69 Möller (2001), 257-258.

70 Further information on the Anagraphe Sikyonia is provided by: Kleingünther (1933), 138-139; Möller (2001), 258-259; BNJ 550.

71 The chronographic tradition does not preserve a list of priestesses. Hence, Toye (1995), 300 argues that Hellanikos did not provide a continuous list at all.

72 Jacoby (1949), 59, 89, 225; Jacoby, FGrHist Ia, 454. 
Steph. Byz. s.v. Chalkis). Diverging from Jacoby's assessment, Burgess and Kulikowski have concluded about the general outline of Hellanikos' Hiereiai: “It was perhaps a synchronism of genealogies and oral traditions more than a thoroughly annalistic chronicle of the type we know from the Hellenistic period."73

Only later in the third century with the Marmor Parium can we really grasp a chronicle that dates each entry with the Attic kings and archons as well as an interval. ${ }^{74}$ The inscription of the island Paros uses the year of Diognetus' archonship in Athens (264/3) as a chronological reference point for the intervals. Nevertheless, the chronicler also referred to the Parian archon's name at the beginning, where the inscription unfortunately shows a break. The text begins with the Attic king Cecrops, whose reign can be converted into the year 1581/0. The preserved lines continue until the year corresponding to 299/8, when Euctemon held the Athenian archonship. Contrary to the fragmentary chronographic evidence, one can clearly see which events of the Greek world were mentioned and which were left out. Despite Athens' obvious role for the chronology, many important political personalities - like Draco, Solon or Cleisthenes - are not considered at all. The same applies to the Olympic Games, large parts of Sparta's history, as well as the Peloponnesian War. Besides political events, the author of the Marmor Parium put an emphasis on cultural, mythical, political and religious aspects, thus including references to the Trojan War, the introduction of minted coins and religious festivals. ${ }^{75}$ Above all, poetry played a prominent role, especially of the Classical period and the late fourth century. ${ }^{76}$ Despite varying content, all entries apply the same formulaic pattern: from the time ( $\dot{\alpha} \varphi$ ' oũ) when $\mathrm{X}$ happened, Y years, when $\mathrm{Z}$ was archon (or king) of Athens. ${ }^{77}$

In the second century Apollodorus wrote a chronicle and according to Jacoby exclusively employed the eponymous Attic archons to express dates for events from the Trojan War until Apollodorus' present. ${ }^{78}$ Jacoby refuted the opinion that Apollodorus might have also used Olympiad dates, which Greek chronographers and authors used at the latest since Hellenistic times. ${ }^{79}$ Apollodorus wrote his

73 Burgess and Kulikowski (2013), 83.

74 For the Marm. Par., see: FGrHist 239; Jacoby (1904a; 1904b); Burgess and Kulikowski (2013), 8485, 301-309 (English translation); Rotstein (2016) (new ed. with English translation); BNJ 239.

75 BNJ 239.

76 A thorough analysis has been conducted by Rotstein (2016), 95-126.

77 Rotstein (2016), 8.

78 For Apollodorus' chronicle, see Jacoby (1902b); Pfeiffer (1968), 253-257; Dorandi (1982); Montanari (1996); Christesen (2007), 13; Feeney (2007), 19-20; Burgess and Kulikowski (2013), 87-88; Fleischer (2020).

79 When exactly Olympiad dates were established in historiography is difficult to assess due to the highly fragmentary evidence at hand. I argue that authors began to use the Olympiad dating system 
chronicle in iambic trimeter, ${ }^{80}$ in which Jacoby saw an argument in favour of archon and against Olympiad dates. ${ }^{81}$ Furthermore, Jacoby commented in this instance on the particular issue that ancient citations could alter the content including the exact wording of dates. The numerous quotes by Diogenes Laertius (ca. third century AD) show in almost all instances Olympiad dates. ${ }^{82}$ Only in two passages does Diogenes actually refer to archon dates. ${ }^{83}$ Therefore, it is comprehensible why some would reason that Apollodorus used both Olympiads and archons. Jacoby ${ }^{84}$ argued that later authors interpolated the Olympiad dates via chronographic tables. ${ }^{85}$ This clearly shows once more the highly challenging situation regarding the fragmentary state of ancient Greek chronography, as already Jacoby has abandoned a strict positivist reasoning. Nevertheless, Apollodorus did not rely exclusively on the Athenian archons for a concise chronology, as he additionally relied upon the Spartan kings according to Diodorus (Diod. Sic. 1.5.1 = FGrHist 244 F61a; first century) and Plutarch (Lyc. 1.2 = FGrHist 244 F62a; second century AD). ${ }^{86}$ The importance of the Attic archons for chronology can also be inferred from the fact that the Augustan author Diodorus used the Attic eponymous officials in addition to the Olympiads, the stadion race winner and the Roman consuls in his Books 11 to $13 .^{87}$

only in the third century parallel to other chronological systems. For methodological problems with the Olympiad dates concerning the Archaic history of the Peloponnese, see the excellent study by Shaw (2003).

80 Jacoby (1902b), 60-74. Ps.-Skymnos (16-49 = FGrHist 244 T2), who wrote his World Journey in iambic trimeters as well, explicitly refers to its metre. Apollodorus, whom Ps.-Skymnos does not mention by name, chose the metric form for mnemotechnic reasons.

81 Pfeiffer (1968), 256; Feeney (2007), 20.

82 FGrHist 244 F14 (ap. Diog. Laert. 4.23), F16 (ap. Diog. Laert. 4.45), F27b (ap. Diog. Laert. 1.79), F28 (Diog. Laert. 1.37), F29 (ap. Diog. Laert. 2.2), F30b (ap. Diog. Laert. 9.29), F31 (ap. Diog. Laert. 2.7), F32a (ap. Diog. Laert. 8.51), F34 (ap. Diog. Laert. 2.33), F36a (ap. Diog. Laert. 9.41), F37 (ap. Diog. Laert. 3.2), F40 (ap. Diog. Laert. 5.58), F46 (ap. Diog. Laert. 7.184), F51 (ap. Diog. Laert. 4.65). F66 (ap. Diog. Laert. 2.3), F68b (ap. Diog. Laert. 9.20), F71 (ap. Diog. Laert. 9.55-56), F72 (ap. Diog. Laert. 9.24), F76 (ap. Diog. Laert. 8.90), F332a (ap. Diog. Laert. 1.95), F332b (ap. Diog. Laert. 1.98), F335c (ap. Diog. Laert. 1.68), F338a (ap. Diog. Laert. 1.121), F340a (ap. Diog. Laert. 9.1), F 341 (ap. Diog. Laert. 9.23), F 343 (ap. Diog. Laert. 2.55), F 344 a (ap. Diog. Laert. 4.1), F 345 (ap. Diog. Laert. 4.14), F346a (ap. Diog. Laert. 4.16), F349a (ap. Diog. Laert. 5.36), F350 (ap. Diog. Laert. 5.68).

83 FGrHist 244 F38a (ap. Diog. Laert. 5.9-10), F42 (ap. Diog. Laert. 10.14-15).

84 Jacoby (1902b), 57 no. 27.

85 According to Polyb. (second century), Timaios (third century) compiled a synchronising list of the Spartan ephors and kings, the Attic archons, the priestesses of Argos and the Olympic victors: BNJ 566 T10 (ap. Polyb. 12.11.1).

86 A recent summary of the evidence of the Spartan king list is provided by Meier (2004); Fleischer (2019).

87 Meister (1990), 174-175; Will (1998), 4; Rathmann (2016), 138. 


\section{A possible influence from the cuneiform chronographic tradition?}

The reason for such a detailed discussion of the fragmentary Greek chronographic evidence in the above section is that it needs to be clear what writings of what date are actually compared to the cuneiform texts. Obviously, the same applies to the other end, in this case the cuneiform evidence, which is fortunately much better preserved. So let us now turn to the eponymous dates of the limmu official in the Neo-Assyrian Empire (910-612). ${ }^{88}$ A couple of seventh-century manuscripts from Nineveh, Assur and Sultantepe have survived. Most of them start with the year corresponding to 910 (Adad-nērāri's office) and end in 649 (Ahu-ilāya's office). It is assumed, however, that such lists must have existed all through the empire for administrative reasons. Nine of the texts just give the list of names, while twelve tablets additionally note historical events. ${ }^{89}$ Therefore, the latter texts belong to the genre of the so-called Eponymous Chronicles. ${ }^{90}$ Each entry consists of the same rigid formula, "in the eponymate of : name : title : event," hence starting in Akkadian with ina lime. These chronicles report for each eponymous year an event, which in most cases refers to military affairs. The style comprises abbreviated forms, as the text only notes the aim (ana place name) or even just a position (ina place name). Scholars generally agree that this information regards the position of the royal army. ${ }^{91}$ The line for the year 781 shall suffice to give an impression of the structure of these entries:

\begin{tabular}{|c|c|c|c|}
\hline ina li-me & ${ }^{\mathrm{md}} \mathrm{DI}-m a-n u-\mathrm{MAŠ}$ & [MAN KUR aš]-šur.KI & $a-n a$ KUR ur-ar-ți $i^{92}$ \\
\hline the eponymate of & Shalmaneser (IV) ${ }^{93}$ & [king of As]syria & to Urartu \\
\hline
\end{tabular}

88 The habit of using the high-ranking official limmu for eponymous dates reaches back into the second millennium, but this is not the focus of the present paper. For the text of the limmu list of the Neo-Assyrian Empire, see Millard (1994); http://oracc.museum.upenn.edu/saao/saas2/corpus (an updated version of Millard's text ed. also with an Akkadian transliteration and English translation). For further discussion of this list, see Millard (ibid.; 1997); Yamada (2018).

89 Millard (1994), 4; Finkel and Reade (1998).

90 For the first-millennium Assyrian Eponymous Chronicles, see Glassner (2004), 164-177 (Akkadian transliteration with English translation). For a possible dialogue between these Neo-Assyrian Eponymous Chronicles and the chronographic genre in Babylonia, see Weissert (1992).

91 Millard (1994), 5; Kah-jjin Kuan (1995), 11.

92 After http://oracc.museum.upenn.edu/saao/saas2/corpus.

93 Assyrian king from 782 to 773 : Baker (2006-2008b). 
Further lines include references to the movement of gods, such as the god of the city Der (831, 814, 785 ), the gods of the city Dur-Sharukkin (707) and the god Nabu of the city Nineveh (787). Also, a solar eclipse (763), the accession of the NeoAssyrian kings Tiglath-pileser III (745) and Shalmaneser V (727) as well as various building activities are mentioned. These chronicles form a valuable source, as they provide a different angle on historic events than the large corpus of the Neo-Assyrian Royal Inscriptions. ${ }^{94}$ The latter - and for that matter the former texts do not form mere objective reports of historical events; rather, their underlying ideologies and worldviews have to be considered. ${ }^{95}$ Thus, already Tadmor ${ }^{96}$ has pointed out the different presentation for Sargon II activities in 712. While Sargon refers to military successes, building measures and metal riches in the so-called Annals ${ }^{97}$, the Eponymous Chronicle merely states that "(the king was) in the land," ina KUR ( $\left.\mathrm{C}^{\mathrm{b}} 4\right)$.

Coming back to the question of a possible influence of these texts on the development of the chronographic genre in Greece, one first has to state the most obvious hindrance: all the cuneiform manuscripts mentioned above date from the seventh century, while the Greek chronographic texts only start in the fifth century. This leaves a gap of roughly 200 years, which makes a direct transmission impossible. Even though the Neo-Babylonian (625-539) and later the Persian Achaemenid Empire (ca. 550-33098) adapted Neo-Assyrian traditions connected to royal ideology, like for example the conception of world dominion, ${ }^{99}$ the fall of Nineveh in 612 constitutes a clear break in the transmission of the Neo-Assyrian text corpora. ${ }^{100}$

The fact that the Neo-Assyrian limmu list and the Eponymous Chronicles existed side-by-side is of particular interest. I have already mentioned above that the chronographic limmu list is explained by practical bureaucratic needs in the Neo-

94 The texts are all edited or in preparation as part of the Royal Inscriptions of the Neo-Assyrian Period. See http://oracc.museum.upenn.edu/rinap/

95 Especially the Italian school of Assyriologists have applied this innovative approach: Fales (1981); Laato (1995); Liverani (1996; 2010a; 2010b; 2014); Tadmor (1997); Fales (1999-2000); Lanfranchi (1999; 2003, 34-36); Ponchia (2016).

96 Tadmor (1958), 95-96.

97 Sargon’s Annals 204-303: Fuchs (1994), 125-152 (Akkadian text), 324-325 (German translation).

98 The reason why the beginning of the Achaemenid Empire cannot be dated precisely, is as follows: “[...] the length of Cyrus' reign is attested [by Babylonian sources] only since he conquered Babylon (539 BC). The length of his earlier Persian rule followed by modern scholars of Near Eastern Studies is unfortunately only an assumption based on Herodotus!" (Kokkinos 2009b, 7 no. 18).

99 Rollinger (2013; 2014b; 2016).

100 For the memory of the Neo-Assyrian Empire in Greek historiography and its possible sources, see Lanfranchi (2000b; 2010; 2011). 
Assyrian Empire. However, the existence of the same name list with historical notations (Eponymous Chronicles) shows a different purpose, which might be located more in the scholarly realm than in state administration. The situation looks different in fifth-century Greece, if we recall the evidence of the Athenian archon list. This chronographic list - or the likely reconstruction thereof - consists only of the officials' names and does not contain any further references. In my opinion, only Hellenistic chronographers fully developed the secondary step, which assigned historical events to specific archons. ${ }^{101}$ This further outlines the different forms of the chronographic genre in the Neo-Assyrian Empire and fifth-century Greece.

If Eusebius' chronicle can indeed provide a reliable insight into Hellenistic chronography - excluding here the Jewish-Christian religious sphere - one might point out certain parallels but also differences between the entries in the NeoAssyrian Eponymous Chronicles and the Greek/Latin text. Both chronographic sources share a certain brevity. However, the Greek/Latin entries do not quite match the briefness of the Akkadian ones. While some entries in the Eponymous Chronicles refer to many events in one or several consecutive lines (e.g. for the years 707, 706, 705 and 704), the description of one single event in Eusebius' chronicle could stretch over a couple of lines, but only provide information on one more complex occasion. It seems noteworthy that Eusebius' lengthier items seem to pertain almost exclusively to Biblical and Roman history. ${ }^{102}$ Rather, most entries in Eusebius' chronicles are very short.

Like the Akkadian texts, the scope of Hellenistic chronography contained "international" notices. In the case of the Eponymous Chronicles, this applies to the military affairs outside the core of the Neo-Assyrian Empire. For the Archaic period Hellenistic chronographers had to refer anyway to the scattered political landscape of the Greco-Roman world. Additionally, they also included regents from its periphery, when important traditions existed in Greek literature. Thus, the Phrygian king(s) Midas, ${ }^{103}$ the Assyrian king Sardanapalus ${ }^{104}$ and the Egyptian phar-

101 This opinion, though, is the subject of debate and I have dedicated a significant part of my dissertation to argue for this approach (Kellner 2019, 38-172). The genealogical sequence of some philosophers and artists distinctively shows a post festum constructed chronology. Fixing the acme of a teacher with the birth of the future pupil allows the chronographers to artificially "determine" the birth and death dates of various important figures. For this diadoche principle, see Mosshammer (1979),113-127. The relationship between chronographic lists and the respective chronicles has as of yet not been the subject of a detailed study and remains a research gap.

102 The longest entry for the Athenian history, as I can see, refers to the change of the lifelong archon to the ten-year office: Helm (1956), 88b $\mathrm{b}^{\mathrm{h}}(754 \mathrm{BC})$.

103 Helm (1956), 53b $b^{\mathrm{i}}(1310 \mathrm{BC}), 89 \mathrm{~b}^{\mathrm{e}}$ (742), 92b $\mathrm{b}^{\mathrm{a}}$ (696).

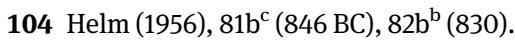


aoh Bokchoris ${ }^{105}$ are mentioned. ${ }^{106}$ This also marks a difference to the Eponymous Chronicles, where for ideological reasons only the Assyrian kings were mentioned by name. ${ }^{107}$ Additionally, references to individuals from the literary and philosophical scope took a prominent place in Greek literary tradition, whereas these are completely missing in the cuneiform texts. Like the Akkadian counterpart, Hellenistic chronography included references to temples, their foundation as well as their destruction ${ }^{108}$ and the field of astronomy with the mention of a solar eclipse. ${ }^{109}$

The similarities shown above seem too generic, at least in my opinion, to allow for an argumentation of a direct transfer from cuneiform to Greek/Latin chronography. Excluding this option, one could still favour the possibility that the eponymous limmu office might have incited the idea for this dating method in Archaic Greece, such as possibly in Athens. This leads directly to the highly controversial discussion of there being an exchange of political concepts between Greece and the Ancient Near East. ${ }^{110}$ The issue of the time gap nevertheless remains, as eponymous dating only starts around 500 in Greece. Hence, I argue that the respective chronographic genres developed independently from each other in their own cultural context. In any case, a close look shows a contextualisation in their own specific literary and cultural background. Furthermore, I would like to draw attention to one crucial difference between the Neo-Assyrian limmu list and in particular the Athenian archon list. Under Ashurbanipal (669-631/27) there seems to have been an increased interest in the past, as the various literary works in the Library of Ashurbanipal attest, ${ }^{111}$ among them the Eponymous Chronicles and the Synchronistic History. ${ }^{12}$ Access was, however, restricted to a special group of people belonging to the Neo-Assyrian elite scribes. The managing of the calendrical system with the appointment of the limmu officials was even the sole

$105 \operatorname{Helm}(1956), 86 b^{\mathrm{i}}(777 \mathrm{BC})$.

106 Obviously, this observation applies to the second part of Euseb.'s chronicle and the spatium historicum. In the first book, Euseb. refers to king lists among others from Manetho and Berossus.

107 The self-representation of some high-ranking officials in the Neo-Assyrian period strongly echoes the form and language of the royal inscriptions. However, certain privileges, especially connected to the religious sphere, were still reserved for their superior, the Assyrian king. See Zaia (2018).

108 Helm (1956), 83b $\mathrm{b}^{\mathrm{e}}$ (814 BC), 90b $\mathrm{b}^{\mathrm{e}}(724), 103 \mathrm{~b}^{\mathrm{g}}(549)$.

$109 \operatorname{Helm}(1956), 100 b^{f}$ (586 BC).

110 E.g. Raaflaub (2011). In this context, I would like to generally point out the Melammu project.

111 Lanfranchi (1999), 60.

112 The Synchronistic History reports the relationship between Assyrian and Babylonian kings from the fifteenth to the eighth centuries with a clear pro-Assyrian bias. For an ed. of the text, see Grayson (1975), 157-170; Glassner (2004), 176-183. 
responsibility of the head of the Neo-Assyrian state. ${ }^{113}$ In contrast, in fifth-century Athens a stele was erected in public where everyone could see the list of the eponymous archons. This makes a strong political message very likely, even though a wholly preserved inscription with its intact archaeological context would have allowed for a more detailed analysis and argumentation. As the letters of this inscription only have an average height of about $1.2 \mathrm{~cm},{ }^{114}$ the question arises whether the Athenian archon list was actually meant to be read. Depending on the details of the original display, one could only read the names properly when standing close to the letters. Other texts from antiquity - like Darius' inscription from Bisutun or the foundation cuneiform texts - have attracted a similar discussion about the intended audience and readership or whether they only served a symbolic function. I propose a certain parallel in the Roman consul list on the arch built by Augustus (27 BC-14 AD) in the Forum Romanum, ${ }^{115}$ which formed part of Augustus' building programme with highly political messages. ${ }^{116}$ Without eliminating the possibility of the Athenian archon list being readable, this line of argumentation rather emphasises the political and symbolic function of this particular chronographic list.

Apart from the Neo-Assyrian sources, the Neo- and Late-Babylonian Chronicles deserve further elaboration regarding the chronographic genre in Mesopotamia, especially since these texts show a continuous text tradition until Hellenistic times and are thus of particular interest for the present inquiry. ${ }^{117}$ What complicates a direct comparison with Greek chronographic traditions is the fact that Babylonian Chronicles are a modern and problematic classification. The tablets from the seventh to second centuries share their annalistic year-by-year entries, but otherwise show great variations in content, focus and even tablet form. ${ }^{118}$ While in the Neo-Assyrian Eponymous Chronicles the annual limmu officials served as the chronological backbone, the Babylonian Chronicles used the numbered years of the kings' reigns. A direct quote from lines o. II 5-8 of the Nabonidus Chronicle (BM 35382), which reports events under Nabonidus (556-539) ${ }^{119}$ and his successor Cyrus the Great, can give an impression of at least this commonly shared characteristic:

113 For the connection of the royal ideology and the Neo-Assyrian king's calendric responsibilities, see Ermidoro (2017).

114 Bradeen (1963), 187-188.

115 For the Fasti Capitolini, see Degrassi (1954); Feeney (2007), 172-183; Burgess and Kulikowski (2013), 160-165.

116 Zanker (1987).

117 While there is a new ed. of the Babylonian Chronicles in preparation by Van der Spek and Finkel, the standard eds. currently available are those by Grayson (1975) and Glassner (2004).

118 For further discussion, see Waerzeggers (2012; 2018).

119 Dandamayev (2001). 


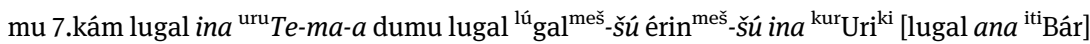
$a-n a \mathrm{E}^{\mathrm{ki}}$ nu gin ${ }^{\mathrm{ku}}{ }^{\mathrm{N}} \mathrm{Na}$ ana Ká.dingir.ra ${ }^{\mathrm{ki}}$ nu gin ${ }^{\mathrm{ku}}{ }^{\mathrm{d}} \mathrm{En}$ nu è ez[en $a$-ki-tú ba-țil] sískur ina $E_{-}$ sag-gíl u É-zi-da dingir ${ }^{\text {meš }}$ ša $\operatorname{Tin}_{\text {tir }}{ }^{\mathrm{ki}} u$ Bár-sipa ${ }^{\mathrm{ki}} k\left[i\right.$ šal-mu sum $^{\mathrm{nu}}$ šeš.gal is-ruq-ma é ip-qid.

"The seventh year, the king stayed in Tayma. The prince, his officers, and his troops stayed in Akkad. [In the month of Nisan, the king] did not go to Babylon. Nabû did not go to Babylon. Bēl did not go out. The fes[tival of the New Year was not celebrated.] The sacrifices to the gods of Babylon and Borsippa were offered in the Esagila and the Ezida a[s in normal times]. The šešgallû-priest made a libation and inspected the temple." ${ }^{20}$

Due to the intertwined political and military history with the surrounding regions, the Babylonian Chronicles also regularly refer to Assyrian and Elamite kings. Especially in contrast to the ideology-laden vocabulary of the Neo-Assyrian Royal Inscriptions, the annalistic and at times dry style of the Babylonian Chronicles has contributed to their reputation of being objective reports, as they (for example) also mention Babylonian defeats. ${ }^{121}$ The focus of recent contributions has, however, shifted away from this approach and rather tried to emphasise that the Babylonian Chronicles present carefully drafted representations of past events. ${ }^{122}$ This applies to the fact that the Babylonian Chronicles report the battle of Der (720) against Sargon's troops and the battle of Halule (691) to have been victorious for the Babylonian side, contrary to the Neo-Assyrian texts. ${ }^{123}$ That those reports should not be understood as entirely neutral accounts is also shown by the negatively connoted term umman-manda for the Medes in the chronicle BM 21901..$^{124}$

Grayson ${ }^{125}$ has argued that a continuous chronicle series recorded the events from Nabonassar's reign (747-734) until Hellenistic times. This view has, however, been refuted, ${ }^{126}$ as the evidence for it relies heavily on the Hellenistic construct of Nabonassar founding a new era. ${ }^{127}$ Another chronological aspect of these cuneiform texts calls for further attention: while the above-mentioned Nabonidus

120 Akkadian transliteration and English translation from Glassner (2004), 234-235.

121 E.g. Grayson (1975), 10.

122 E.g. Van de Mieroop (2012), 38: "History writing is never innocent; it reflects the concern and interests of the author at the moment of writing.” Earlier Assyriological studies have developed and applied this sort of approach; see e.g. Liverani (1973); Hallo (1998).

123 Melville (2014), 534-535.

124 Grayson (1975), 90-96; Glassner (2004), 218-225; Zawadzki (1988a). For the term ummanmanda, see CAD U-W s.v. ummān-manda 102; Liverani (1988; 2017, 60-61); Zawadzki (1988b); Adalı (2011).

125 Grayson (1975), 8-28.

126 Glassner (2004), 44; Waerzeggers (2012), 286-287.

127 The era of Nabonassar was probably invented in Hellenistic times and can also be found in the Ptolemaic Royal Canon. Hallo (1988), 186-190; Glassner (2004), 111-113; Liverani (2010a), 51. 
Chronicle deals with the sixth century, the tablet was actually written in Seleucid times, ${ }^{128}$ and therefore at least 200 years after the reported events. Thus, Waerzeggers has proposed to understand this tablet as a product of "historical literature," which addresses the question of a possible dialogue with Greek historiography in this period. ${ }^{129}$ This circumstance is not restricted to one particular text, but applies to other tablets as well. ${ }^{130}$ Obviously, the circumstances of Hellenistic times form firmer ground when looking for a possible dialogue between different writing traditions, especially if one bears in mind the evidence of Berossus and the GraecoBabyloniaca (clay tablets with Akkadian/Sumerian texts and Greek transliteration). What traces of interaction these late texts portray remains the subject of future research.

Looking for a possible influence of cuneiform chronographic tradition on the development of similar writings in fifth-century Greece, one would ideally demand a date in the late sixth and fifth centuries. However, with one possible exception $^{131}$ there are no Babylonian Chronicles known from this time. Further studies might be able to show if this is indeed purely incidental or of crucial significance for the Persian Achaemenid period. The current state of research shows that a direct line of transmission from the Babylonian Chronicles to early Greek chronographic texts cannot be drawn. Once more, I would like to emphasise that the evidence points to an independent development of chronography in Mesopotamia and Greece to the fifth century. The generic similarities mainly consist of eponymous dating and abbreviated notes, which in my opinion reflect practical reasons and do not reveal deeper underlying connections.

\section{Temple histories in antiquity}

While my answer to a possible dialogue between chronography in ancient Greece and Mesopotamia has so far been rather negative, I would like now to suggest a different approach to these chronographic texts. They provide valuable testimonies and therefore insights into their cultural, regional and local context, as I aim to demonstrate in the last section of this paper. I would like to suggest a compar-

128 Glassner (2004), 232.

129 Waerzeggers (2015), especially 96, 115-116.

130 Glassner (2004), 210 (BM 96273 = Šamaš-šuma-ukin Chronicle), 206 (BM 25091 = Esarhaddon Chronicle).

131 One copy (BM 92502) of the chronicle about the period from Nabonassar to Šamaš-šuma-ukin bears a colophon (r. IV 43) with the date of the $22^{\text {nd }}$ (?) year of a king, whose name is difficult to read but could refer to Darius I. Glassner (2004), 193. 
ison of written temple histories in antiquity. Places of worship universally possess an outstanding status not only due to their veneration of gods but also regarding the preservation of a society's past. ${ }^{132}$ Significantly, there exist preserved texts in the cuneiform and classical tradition alike. I will analyse them as a positive contribution to the assessment of the chronographic traditions in Greece and Mesopotamia, which are deeply rooted in their respective cultural and sociopolitical settings.

Let us first have a look at Mesopotamia, where clay bricks made it necessary to regularly conduct restorations or to entirely rebuild temples. Various kings ordered the meticulous (re)building of temples on the same foundations over millennia. ${ }^{133}$ For example, the Neo-Assyrian king Esarhaddon (681-669) ${ }^{134}$ can thus report in an exceptional Akkadian inscription (Leichty 2011, 119-129 nr. 57 = Ass. A.) the history of the Assur temple in Assur:

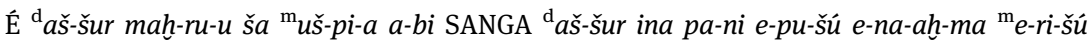
DUMU ${ }^{\mathrm{m} D I N G I R-s ̌ u m-m a ~ a-b i ~ S A N G A}{ }^{\mathrm{d}} a \check{s}$-šur e-pu-uš 2 UŠ 6 MU.AN.NA.MEŠ il-lik-ma i-tur

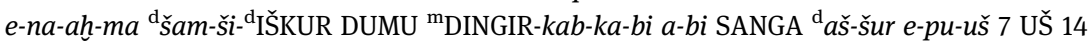
MU.AN.NA.MEŠ il-lik-ma É šu-ú ina qí-mì-it ${ }^{\mathrm{d}} \mathrm{GIŠ}$.BAR uš-tal-pit ${ }^{\mathrm{m} d}$ šùl-ma-nu-MAŠ DUMU ${ }^{\mathrm{md}}$ IŠKUR-ERIM.TÂH $a$-bi SANGA ${ }^{\mathrm{d}} a{ }_{\text {Ššur }}$ e-pu-uš 9 UŠ 40.ÀM MU.AN.NA.MEŠ il-lik-ma É $p a$ -

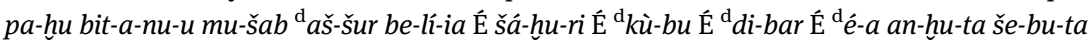
la-bi-ru-ta il-li-ku-ma

"The former temple of the god Aššur, which Ušpia, my ancestor, priest of the god Aššur, first built, became dilapidated and Erišum (I), son of Ilušūmua, my ancestor, priest of the god Aššur, (re)built (it); 126 years passed and it became dilapidated again, and Šamšī-Adad (I), son of Ilā-kabkabī, my ancestor, priest of the god Aššur, (re)built (it); 434 years passed and that temple was destroyed in a conflagration, (and) Shalmaneser (I), son of Adadnārārī (I), my ancestor, priest of the god Aššur, (re)built (it); 580 years passed and the inner cella, the residence of the god Aššur, my lord, the bit-šahūru, the temple of the god Kubu, the temple of the god Dibar, (and) the temple of the god Ea became dilapidated, aged, (and) antique.”135

Esarhaddon thus mentions his predecessor Ušpia in the third millennium, who first erected the temple, and Erišum I, Šamši-Adad I and Shalmaneser I (12731244), ${ }^{136}$ who all conducted restoration works. Additionally, the inscription pro-

132 Galter (2004): Assur temple in Assur. Clancier (2009), 168-213: Esagila temple in Babylon. Haake and Jung (2011) for Greek temples in general.

133 Galter (2004), 122-123. For an analysis of temple building in Assyria and Babylonia, see Novotny (2010); Schaudig (2010).

134 Weißbach (1928); Bagg (2008).

135 Ass. A. III 16-41. Akkadian transliteration and English translation according to Leichty (2011), 124-125.

136 Baker (2006-2008a). 
vides the information how many years elapsed between the construction works since Erišum I. Hence, this inscription obviously contains valuable information for the absolute chronology of the third and second millennia. ${ }^{137}$ It clearly shows an awareness of the temple's high age, as was evident by building documents left by Esarhaddon's predecessors. The scribes expressed the immense time spans with precise numbers relying on the Assyrian King List ${ }^{138}$ for this singular instance of interval dating in Neo-Assyrian times.

It is the following Neo-Babylonian period, though, that Beaulieu has termed "the age of antiquarianism par excellence". ${ }^{139}$ Especially king Nabonidus (556539) has been attributed a deep historical interest that supposedly led him to actively search for the foundation inscriptions of previous kings at various sanctuaries, as his inscriptions attest. ${ }^{140}$ Instead of ascribing Nabonidus exclusively scholarly ambitions one probably should understand Nabonidus' active interest in the glorious past of ancient kings as a form of legitimisation and self-representation. ${ }^{141}$ Not only does Nabonidus frequently refer to the foundation deposits or building documents of his predecessors, in three instances he also gives exact intervals, like Esarhaddon in the previous text passage. When rebuilding the Ebabbar temple dedicated to Šamaš in Sippar, Nabonidus claims to have found the 3,200year-old foundations of the Akkadian king Naram-Sin. ${ }^{142}$ In this context, it is moot to point out that the provided number is roughly 1,000 years too high, ${ }^{143}$ probably caused by the artificial concept of only one ruling dynasty in Mesopotamia, when there were in reality parallel political entities. ${ }^{144}$ This text passage depicts a fascinating example of how ancient scholars made use of the king lists and actually connected a distant past with their present. In the same text Nabonidus also reports

137 As there is no consensus about the exact date of Ušpia, Erišum I and Šamšī-Adad I, no absolute dates have been provided in the text above. Several studies have dealt with the question whether this inscription can contribute to solving the chronological issues for third- and second-millennium Assyria. Note that scholars generally assume that instead of 580 years one has to assume 586 years between Esarhaddon and Shalmaneser I. The necessity of an emendation also applies to the number 434, which has been corrected to 494. For further details and the topic of the Assyrian Distanzangaben in general, see Gasche, et al. (1998), 57-61; Pruzsinszky (2002-2005; 2006); Eder (2004). 138 Grayson (1983), 101-124.

139 Beaulieu (1994), 40. For an overview of antiquarianism in Mesopotamia, see Rubio (2009).

140 Schaudig (2003).

141 Schaudig (2003), 447-449.

142 2.121 II 57: Schaudig (2001), 422 (Akkadian transliteration); 438 (German translation).

143 Schmidtke (1947-52).

144 The Sumerian King List most notoriously follows this concept: Jacobsen (1939). However, there exist a number of later king lists that provide the names of the rulers of Assyria and Babylonia side-by-side: Grayson (1983), 116-126. 
the rebuilding of the E'ulmaš temple of the goddess Anunitu in Sippar, where the foundations were laid by Šagarakti-Šuriaš (thirteenth century) $)^{145} 800$ years before Nabonidus' time. ${ }^{146}$ Besides those two remarkable examples, where the scribes undertook the effort to precisely name the elapsed time via the king lists, in most instances the mere reference to a predecessor seemed sufficient. In the course of his building works, Nabonidus thus mentions Sargon (twenty-fourth/twenty-fifth century), ${ }^{147}$ Naram-Sin (twenty-third century), ${ }^{148}$ Ur-Namma and Šulgi (twenty-first/ twentieth century), ${ }^{149}$ Enanedu (sister of king Rim-Sin eighteenth century), ${ }^{150}$ KuriGalzu I (fifteenth/fourteenth century), ${ }^{151}$ Šagarakti-Šuriaš (thirteenth century), ${ }^{152}$ Nebukadnezar I (twelfth century BC), ${ }^{153}$ Shalmaneser II (eleventh century), ${ }^{154}$ Esarhaddon (681-669) ${ }^{155}$ and Ashurbanipal (669-631/27). ${ }^{156}$

While a couple of instances in Mesopotamia are thus known, to the best of my knowledge there exists only one Greek account of a temple's past, namely of the Athena temple in Lindos on Rhodes. This text is commonly referred to as the Lindian Temple Chronicle, ${ }^{157}$ a slightly misleading designation, as will become clear when considering the content. The stele has the impressive height of $2.37 \mathrm{~m}$ and contains four sections (A-D). At the top (A) one finds the information that the Lindians and their officials have decided that the numerous offerings to Athena should be put in a register, because many objects or their inscriptions have perished in the course of time. Thus, two individuals, Tharsagoras and Timakhidas, ${ }^{158}$

145 The precise dates of the various kings of the third and second millennia are rather diverging, depending on what chronology (high, middle or short) one prefers.

146 2.1211 III 28-34: Schaudig (2001), 425 (Akkadian transliteration), 439 (German translation).

147 2.14 4 I 15-21: Schaudig (2001), 448 (Akkadian transliteration), 461 (German translation).

148 P 4 III 21'-IV 5: Schaudig (2001), 592 (Akkadian transliteration), 594 (German translation), 2.14 2 II 69-74: Schaudig, ibid., 456 (Akkadian transliteration), 464 (German translation).

149 2.21 I 5-18: Schaudig (2001), 351 (transliteration), 352 (German translation).

150 2.7 II 1-5: Schaudig (2001), 374 (transliteration), 376-377 (German translation).

151 2.14 2 II 28-36: Schaudig (2001), 454 (Akkadian transliteration), 463 (German translation).

152 2.14 2 III 38-65: Schaudig (2001), 457-459 (Akkadian transliteration), 465-466 (German translation).

153 2.7 I 29-35: Schaudig (2001), 374 (Akkadian transliteration), 376 (German translation), P4 III 5'-10': Schaudig, ibid., 591-592 (Akkadian transliteration), 593-594 (German translation).

1542.1211 I 47-49: Schaudig (2001), 418-419 (Akkadian transliteration), 437 (German translation).

155 2.14 II 37-45: Schaudig (2001), 454-455 (Akkadian transliteration), 463 (German translation). 1562.1211 II 42-45: Schaudig (2001), 421-422 (Akkadian transliteration), 438 (German translation), 2.14 II 37-45: Schaudig, ibid., 454-455 (Akkadian transliteration), 463 (German translation). 157 For the Greek text with an English translation, see BNJ 532; Higbie (2003), $21-49$.

158 Timakhidas might be identical with Timakhidas of Rhodes, who was a philologist and poet as well as the author of now lost works: Blinkenberg (1915), 41-47. 
were chosen to fulfil this task. This decree dates to the year of Teisylos' priesthood (99). ${ }^{159}$ After this section, the entries of prestigious votive objects follow in two columns (B and C), which range from far distant (mythical) times (entries I-XIV), the Archaic period (XV-XXXI), the Persian Wars (XXXII-XXXV) to later centuries (XXXIII-XLII). The entries do not contain absolute dates, but for the most part imply a relative chronology starting with the oldest known objects. ${ }^{160}$ Entry XVII serves to give an insight in the form and nature of this inscription:

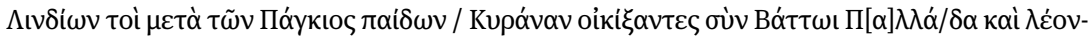

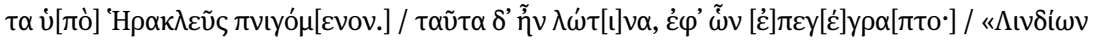

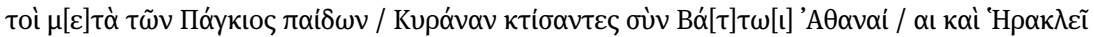

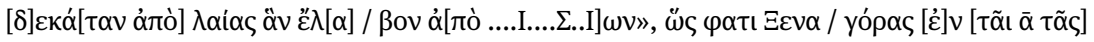

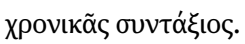

"Those of the Lindians who with the children of Pankis colonized Cyrene with Battos, Pallas and a lion being strangled by Herakles. These were of lotus wood, on which had been inscribed: 'those of the Lindians who with the children of Pankis founded a colony on Cyrene with Battos to Athena and to Herakles a tenth of the booty which they took from ...' as Xenagoras states in the first book of his Annalistic Account.”"161

Thus, the dedicated objects not only told the history of the Athena temple in Lindos, but also highlighted the sanctuary's importance in an over-regional past. The above passage exemplifies the temple's Panhellenic role with a reference to the foundation of Cyrene in Libya (late seventh century). ${ }^{162}$ Especially for the earlier dedications, such as in the entry quoted above, the inscription refers to other authors - most of them probably Rhodian - and not to the objects themselves, thereby providing a fascinating case of citation in classical antiquity. ${ }^{163}$

The third column (D) of the Lindian Temple Chronicle recounts three epiphanies of the goddess Athena. The goddess gave advice twice during a siege and once helped to clear cultic matters for her own temple. In this section, the inscription shows two eponymous dates, ${ }^{164}$ this time not referring to a priest of Athena

159 Via a list of priests of Athena one can place Teisylos' office to 99: Blinkenberg (1941), 60-147.

160 Higbie (2003), 164.

161 Greek text and English translation after BNJ 532 F2.

162 The foundation of Cyrene is foremost told by Hdt. 4.150-159 and plays an immanent role in Pind. Pyth. 4, which also does not mention any other participating group besides the one around Battos from Thera. For a discussion of this deviation, see Ryan (2001). Various authors supply a foundation date for Cyrene: Hdt. 2.161-163, 4.157-158.1, 4.159.1; Theophr. Hist. pl. 6.3.3; Plin. HN 19.41; Solin. 27.44; Jer. (Helm 1956, 52b $\mathrm{b}^{\mathrm{e}}$, 87b $\mathrm{b}^{\mathrm{h}}, 96 \mathrm{~b}^{\mathrm{k}}$ ); Armenian Euseb. (Karst 1911, 167, 181, 185).

163 For a further discussion of the sources of the Lindian Temple Chronicle, see Higbie (2003), 189-203; BNJ 253.

164 BNJ 253 F4 39-40, F 461. 
but instead to the priests of the sun god Halios. Under the priesthood of Eukles many dedications were destroyed by fire, maybe providing the reason why such a project was necessary in the first place. ${ }^{165}$ At the time of the inscription (99), Rhodes was under the political influence of Rome and had therefore already lost its political independence. Without overstretching an interpretation of the circumstances, one can imagine this inscription to have played a significant role in the self-representation of the Lindians. ${ }^{166}$

The direct comparison of Greek, Assyrian and Babylonian chronographic traditions is a highly complicated subject. While the transfer of literary motifs and narrative patterns can be shown in other genres, the fragmentary evidence for the Greek texts beginning in the fifth century impedes such an approach immensely. A re-evaluation and discussion of the interpretative concepts pioneered by Jacoby have shown that it is indeed rather challenging to draw a concise picture of fifthcentury Greek chronography. This also applies to the local histories of Athens (Atthides), where the fragments do not permit an easy conclusion for the assumed annalistic pattern. Looking for cuneiform sources which might have influenced the development of similar writings in Greece, especially the eponymous limmu office of the Neo-Assyrian Empire, warrants attention. While the limmu list served as the chronological backbone of the Eponymous Chronicles similarly to the Athenian archons, there remains a huge time gap between the end of the NeoAssyrian Empire in the late seventh-century and the fifth-century Greek texts. A similar time gap applies to the Babylonian Chronicles regarding fifth-century Greek chronography. In this specific instance, the mentioned cuneiform sources can add little to illuminate the fragmentary fifth-century Greek chronographic evidence. Hence, I suggest that the chronographic genres developed independently from each other, which is further supported by my analysis that the form and content of these texts only show superficial similarities. I would rather explain these generic resemblances like brevity in style and eponymous dating with the universal practical needs of the chronographic genre. As previous contributions have only touched upon this topic in passing, the value of the present contribution lies primarily in the detailed presentation and discussion of the actual evidence at hand. In the last section of the paper, I have presented chronographic texts relating to the past of important sanctuaries in Akkadian and Greek texts as test cases. The Neo-Assyrian king Esarhaddon and the Neo-Babylonian king Na-

165 BNJ 253 F4 29-42. Two dates have been suggested for Eukles' office, namely 391/0 (Higbie 2003, 7) and 342 (Blinkenberg 1941, 157-158, 198-200). The date 391/0 is the result of circular reasoning. However, in this context the difference of roughly 50 years does not play a great role, hence the reader is referred to the discussion of the evidence in Gabrielsen (2000), 187, 202 no. 49.

166 Higbie (2003), 243. 
bonidus both referred to building inscriptions of their predecessors, when they themselves conducted construction works on several temples. The written documents with the various king lists in Mesopotamia allowed the ancient scholars to reflect on a far distant past reaching back into the third millennium. The background for the only comparable written history of a Greek temple looked quite different: the loss of the votive offerings to Athena Lindia in her temple led to the commission of the Lindian Temple Chronicle in the first century. With this stele, the Lindians wanted to ensure the preservation of otherwise now lost objects in the temple and conserve their place in the Greco-Roman world. While all these texts share a common interest for a sanctuary's past, the specific form and focus differ according to their respective literary, political and societal settings. I think that this methodological approach merits attention, as ancient texts can accordingly provide valuable insights into the different societies of antiquity.

Acknowledgements: I would like to thank Profs. Rocío Da Riva, Jennifer Finn, Irene Madreiter as well as the anonymous reviewer of my paper. In addition, I want to express my gratitude to Prof. Caroline Waerzeggers for generously sharing a back then unpublished article. Funding for this research was provided by the DOC Fellowship of the Austrian Academy of Sciences at the Institute of Ancient History and Ancient Near Eastern Studies at the University of Innsbruck.

\section{Bibliography}

Adalı, S. The Scourge of God. Helsinki: Neo-Assyrian Text Corpus Project, 2011.

Adler, W. "Eusebius' chronicle and its legacy." In Eusebius, Christianity and Judaism, edited by F. Attridge and G. Hata, 467-491. Leiden: Brill, 1992.

Alexander, J. "Was Cleisthenes an Athenian archon?" CJ 54 (1958/9): 307-314.

Ambaglio D. L'opera storiografica die Ellanico di Lesbo. Pisa: Giardini editori e stampatori in Pisa, 1980.

Bagg, A. “Asarhaddon” In Das wissenschaftliche Bibellexikon, edited by M. Bauks, K. Koenen and S. Alkier. http://www.bibelwissenschaft.de/stichwort/13973/. 2008. Accessed Jul. 7, 2017.

Baker, H. "Salmanassar I." In Reallexikon der Assyriologie und vorderasiatischen Archäologie 11, edited by M. Streck, 579-580. Berlin: De Gruyter, 2006-2008a.

Baker, H. "Salmanassar IV." In Reallexikon der Assyriologie und vorderasiatischen Archäologie 11, edited by M. Streck, 585. Berlin: De Gruyter, 2006-2008b.

Ball R. Chronography and Early Greek History. PhD thesis, University of Oxford, 1974.

Baron, C. Timaios of Tauromenium and Hellenistic Historiography. Cambridge: Cambridge U. P., 2013.

Beaulieu, P. "Antiquarianism and the concern for the past in the Neo-Babylonian period." Bulletin of the (Canadian) Society for Mesopotamian Studies 28 (1994): 37-42. 
Bichler, R. “Das chronologische Bild der „Archaik“.” In Rollinger and Ulf 2004, 207-245.

Blinkenberg, C. Die lindische Tempelchronik. Bonn: Marcus \& Weber, 1915.

Blinkenberg, C. Lindos. Fouilles de l'Acropole 1902-1914 II. Inscriptions 1 (n 1-281). Berlin: De Gruyter, 1941.

Bradeen, D. “The fifth-century archon list.” Hesp. 32 (1963): 187-208.

Brunt, P. “On historical fragments and epitomes." CQ 30 (1980): 477-494.

Burgess, R. Studies in Eusebian and Post-Eusebian Chronography. Stuttgart: Steiner, 1999.

Burgess, R. "Jerome explained: an introduction to his chronicle and a guide to its use." AHB 16 (2002): 1-32.

Burgess, R. and M. Kulikowski. Mosaics of Time I. Turnhout: Brepols, 2013.

Burkert, W. Die orientalisierende Epoche in der griechischen Religion und Literatur. Heidelberg: Winter, 1984.

Burkert, W. The Orientalizing Revolution. Cambridge, MA: Harvard U. P., 1992.

Busolt, G. Griechische Geschichte bis zur Schlacht bei Chaironeia II. 2nd ed. Gotha: Perthes, 1895.

CAD = Oppenheim, A., E. Reiner, et al., editors. The Assyrian Dictionary of the University of Chicago, Chicago: Oriental Institute, 1956-2010.

Chambers, M. Aristoteles. Staat der Athener, Berlin: De Gruyter, 1990.

Chaniotis, A. "Eponyme Datierung II. Griechenland und Rom.” In Der Neue Pauly 4, edited by H. Cancik, 3-8. Stuttgart: Metzler, 1998.

Christesen, P. Olympic Victor Lists and Ancient Greek History. Cambridge: Cambridge U. P., 2007.

Christesen, P. and Z. Martirosova-Torlone. "The Olympic Victor List of Eusebius: background, text, and translation." Traditio 61 (2006): 31-93.

Clancier, P. Les bibliothèques en Babylonie dans la deuxième moitié du ler millénaire av. J.-C. Münster: Ugarit, 2009.

Croke, B. “The originality of Eusebius' chronicle.” AJPh 103 (1982): 195-200.

Dalley, S., editor. The Legacy of Mesopotamia. Oxford: Oxford U. P., 1998.

Dandamayev, M. “Nabonid." In Reallexikon der Assyriologie und vorderasiatischen Archäologie 9, edited by P. Calmeyer and M. Streck, 6-11. Berlin: De Gruyter, 2001.

Degrassi, A. Fasti Capitolini. Turin: Paravia, 1954.

Dillon, M. "Was Kleisthenes or Pleisthenes archon at Athens in 525 BC?" ZPE 155 (2006): 91-107.

Dorandi, T. 1982, La Cronologia di Apollodoro nel Pherc. 1021. Naples: Giannini, 1982.

Drost-Abgarjan, A. "Ein neuer Fund zur armenischen Version der Eusebios-Chronik." In Julius Africanus und die christliche Weltchronistik, edited by M. Wallraff, 255-262. Berlin: De Gruyter, 2006.

Eder, C. "Assyrische Distanzangaben und die absolute Chronologie Vorderasiens." AoF 31 (2004): 191-236.

Ehrhardt, N. "Athen im 6. Jhv. v.Chr.: Quellenlage, Methodenprobleme und Fakten.” In Euphronios und seine Zeit, 12-23. Berlin: Staatliche Museen zu Berlin, 1992.

Ermidoro, S. "Ruling over time. The calendar in the Neo-Assyrian royal propaganda." SAAB 23 (2017): 131-156.

Fales, M., editor. Assyrian Royal Inscriptions. Rome: Istituto per l'Oriente, 1981.

Fales, M. “Assyrian royal inscriptions: newer horizons." SAAB 13 (1999-2000): 115-144.

Feeney, D. Caesar's Calendar. Berkeley: University of California, 2007.

Fink, S. and R. Rollinger, editors. Conceptualizing Past, Present and Future. Münster: Ugarit, 2018. 
Finkel, I. and J. Reade. “Assyrian eponyms 873-649 BC.” Orientalia 67 (1998): 248-254.

Finn, J. “Herodotus' Poor Man of Nippur.” CW 112 (2019): 13-38.

Fleischer, K. "Die älteste Liste der Könige Spartas: Pherekydes von Athen (Pherc. 1788, Col.1)." ZPE 209 (2019): 1-24.

Fleischer, K. The Original Verses of Apollodorus' Chronica. Berlin: De Gruyter, 2020.

Fowler, R. “Herodotus and his contemporaries.” JHS 116 (1996): 62-87.

Fowler, R. Early Greek Mythography II. Oxford: Oxford U. P., 2013.

Fuchs, A. Die Inschriften Sargons II. aus Khorsabad. Göttingen: Cuvillier, 1994.

Funke, P. "Einige Überlegungen zur Genese der antiken griechischen Lokalgeschichtsschreibung." Geographia Antiqua 23/24 (2014/5): 179-185.

Gabrielsen, V. "The synoikized polis of Rhodes." In Polis and Politics, edited by P. FlenstedJensen, T. Nielsen and L. Rubinstein, 177-205. Copenhagen: Museum Tusculanum, 2000.

Galter, H. "Geschichte als Bauwerk: der Aššurtempel und das assyrische Geschichtsbewusstein." In From the Upper Sea to the Lower Sea, edited by G. Frame and L. Wilding, 117-135. Leiden: Nederlands Inst. voor het Nabije Oosten, 2004.

Gasche, H., J. Armstrong, S. Cole and V. Gurzadyan. Dating the Fall of Babylon. Chicago: Oriental Institute.

Gehrke, H.-J. Geschichte als Element antiker Kultur. Berlin: De Gruyter, 2014.

Glassner, J.-J. Mesopotamian Chronicles. Atlanta: Society of Biblical Literature, 2004.

Gomme, A. A Historical Commentary on Thucydides II. Oxford: Clarendon, 1962.

Grafton, A. and M. Williams. Christianity and the Transformation of the Book. Cambridge, MA: Belknap, 2006.

Grayson, A. Assyrian and Babylonian Chronicles. New York: J. J. Augustin, 1975.

Grayson A. "Königslisten und Chroniken B. Akkadisch." In Reallexikon der Assyriologie und Vorderasiatischen Archäologie 6, edited by M. Streck, 86-135. Berlin: De Gruyter, 1983.

Gufler, B. and I. Madreiter. "The Ancient Near East and the genre of Greek historiography." In Mesopotamia in the Ancient World, edited by R. Rollinger and E. van Dongen, 381-396. Münster: Ugarit, 2015.

Haake, M. and M. Jung, editors. Griechische Heiligtümer als Erinnerungsorte. Stuttgart: Steiner, 2011.

Hall, J. Ethnic Identity in Greek Antiquity. Cambridge: Cambridge U. P., 1997.

Hallo, W. "The Nabonassar era and other epochs in Mesopoamian chronology and chronography." In A Scientific Humanist, edited by E. Leichty, M. De J. Ellis and P. Gerardi, 175-190. Philadelphia: University Museum, 1988.

Hallo, W. "New directions in historiography (Mesopotamia and Israel)." In dubsar anta-men, edited by M. Dietrich and O. Loretz, 109-128. Münster: Ugarit, 1998.

Hanell, K. Das altrömische eponyme Amt. Lund: Gleerup, 1946.

Harding, P. "Local history and Atthidography." In A Companion to Greek and Roman Historiography, edited by J. Marincola, 181-183. Chichester: Wiley-Blackwell, 2007.

Harding, P. The Story of Athens. London: Routledge, 2008.

Haubold, J. Greece and Mesopotamia. Cambridge: Cambridge U. P, 2013.

Helm R. "Eusebius' Chronik und ihre Tabellenform." Abhandlungen der Preussischen Akademie der Wissenschaften, philosophisch-historische Klasse Jahrgang 1923. Berliner Akademie 4 (1924): 1-56.

Helm, R. Eusebius Werke VII. Berlin: Akademie-Verlag, 1956.

Higbie, C. The Lindian Chronicle and the Greek Creation of their Past. Oxford: Oxford U. P., 2003.

Hignett, C. A History of the Athenian Constitution. Oxford: Clarendon, 1952. 
Hind, J. “The „Tyrannis“ and the exiles of Pisistratus.” CQ 24 (1974): 1-18.

Hornblower, S. Greek Historiography Oxford: Clarendon, 1994.

Jacobsen, T. The Sumerian King List. Chicago: Chicago U. P., 1939.

Jacoby, F. “Die attische Königsliste I.” Klio 2 (1902a): 406-439.

Jacoby, F. Apollodors Chronik. Berlin: Weidmann, 1902b.

Jacoby, F. Das Marmor Parium. Berlin: Weidmann, 1904 a.

Jacoby F. “Über das Marmor Parium.” RhM 59 (1904b): 63-107.

Jacoby F. "Über die Entwicklung der griechischen Historiographie und den Plan einer Sammlung der griechischen Historikerfragmente." Klio 9 (1909): 80-123.

Jacoby, F. Atthis. Oxford: Clarendon, 1949.

Joyce, C. "Was Hellanikos the first chronicler of Athens?" Histos 3 (1990): 1-17.

Kah-jjin Kuan, J. Neo-Assyrian Historical Inscriptions and Syria-Palestine. Hong Kong: Alliance Bible Seminary, 1995.

Karst, J. Eusebius Werke V. Leipzig: Hinrichs, 1911.

Kellner, A. Die Chronologie der griechischen Archaik. PhD thesis, University of Innsbruck, 2019.

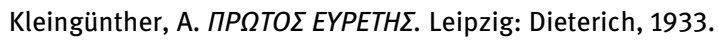

Kokkinos, N. "Ancient chronography, Eratosthenes and the dating of the fall of Troy." Ancient West \& East 8 (2009a): 37-56.

Kokkinos, N. "Re-dating the fall of Sardis." SCl 28 (2009b): 1-23.

Kokkinos, N. "The Tyrian annals and ancient Greek chronography." SCI 32 (2013): 21-66.

Kõiv, M. "The dating of Pheidon in antiquity." Klio 83 (2001): 327-347.

Laato, A. "Assyrian propaganda and the falsification of history in the royal inscriptions of Sennacherib.” VT 45 (1995): 198-226.

Lanfranchi, G. “Le iscrizioni reali assire." In Presentazione e scrittura della storia, edited by E. Gabba, 43-60. Como: Edizioni New, 1999.

Lanfranchi, G. "The oracle of Apollo to Croesus, Mesopotamian astrology and mathematical astronomy in Herodotus' Histories.” In Patavina Orientalia Selecta, edited by E. Rova, 261-278. Padua: Sargon, 2000a.

Lanfranchi G. "The ideological and political impact of the Neo-Assyrian imperial xxpansion on the Greek world in the 8th and 7th centuries BC." In Melammu Symposia I, edited by S. Aro and R. Whiting, 7-34. Helsinki: Neo-Assyrian Text Corpus Project, 2000 b.

Lanfranchi, G. "Imperi assiro, babilonese, persiano: continuità e discontinuità.” In La successione degli imperi e delle egemonie nelle relazioni internazionali, edited by $\mathrm{D}$. Foraboschi and S. Pizzetti, 27-47. Milan: Unicopli, 2003.

Lanfranchi, G. "Greek historians and the memory of the Assyrian court." In Der Achämenidenhof / The Achaemenid Court, edited by B. Jacobs and R. Rollinger, 39-65. Wiesbaden: Harrassowitz, 2010.

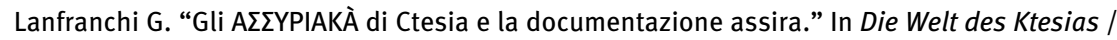
Ctesias' world, edited by J. Wiesehöfer, R. Rollinger and G. Lanfranchi, 175-223. Wiesbaden: Harrassowitz, 2011.

Lang, M. "Floating from Babylon to Rome. Ancient Near Eastern flood stories in the Mediterranean world." Kaskal 5 (2008): 211-231.

Ledl, A. Studien zur älteren athenischen Verfassungsgeschichte. New York: Arno, 1973.

Leichty, E. The Royal Inscriptions of Esarhaddon, King of Assyria (680-669 BC). Winona Lake: Eisenbrauns, 2011.

Lenardon, R. "Thucydides and Hellanikos." In Classical Contributions, edited by G. Shrimpton and D. McCargar, 59-70. Toronto: University of Toronto, 1981. 
Liverani, M. “Memorandum on the approach to historiographic texts." Orientalia 42 (1973): 178-194.

Liverani, M. “Uomini, forse.” VicOr. 7 (1988): 253-255.

Liverani, M. "Ancient propaganda and historical criticism." In The Study of the Ancient Near East in the Twenty-First Century, edited by J. Cooper and G. Schwartz, 283-289. Winona Lake: Eisenbrauns, 1996.

Liverani, M. “Parole di bronzo, di pietra, d'argilla” Scienze dell'antichità 16 (2010a): 27-63.

Liverani, M. “'Untruthful Steles.' Propaganda and reliability in ancient Mesopotamia." In Opening the Tablet Box, edited by S. Melville and A. Slotsky, 229-244. Leiden: Brill, 2010b.

Liverani M. "The king and his audience." In From Source to History, edited by S. Gaspa, et al., 373-386. Münster: Ugarit, 2014.

Liverani, M. Assyria. Winona Lake: Eisenbrauns, 2017.

Marincola, J. "Genre, convention and innovation in Greco-Roman historiography." In The Limits of Historiography, edited by C. Kraus, 281-324. Leiden: Brill, 1999.

Marincola, J. "Introduction: a past without historians." In Greek Notions of the Past in the Archaic and Classical Era, edited by J. Marincola, L. Llewellyn-Jones and C. Maciver, 1-13. Edinburgh: Edinburgh U. P., 2012.

Márquez Rowe, I. "Homer's origin of all things and Babylonian cosmogony. Revisiting Burkert's thesis." In Fink and Rollinger 2018, 369-380.

Meier, M. "X. 2 Könige von Sparta." In Herrscherchronologien der antiken Welt. Der Neue Pauly Suppl. 1, edited by W. Eder and J. Renger, 180-183. Stuttgart: Metzler, 2004.

Meiggs, R. and D. Lewis. A Selection of Greek Historical Inscriptions to the end of the Fifth Century $B C$. Oxford: Clarendon, 1969.

Meister, K. Die griechische Geschichtsschreibung. Stuttgart: Kohlhammer, 1990.

Melville, S. "Win, lose or draw? Claiming victory in battle." In Krieg und Frieden im Alten Vorderasien, edited by H. Neumann, et al., 527-537. Münster: Ugarit, 2014.

Michalowski, P. “The strange history of Tumal.” In Studies in Honour of Stip (H. L. J. Vanstiphout), edited by P. Michalowski and N. Veldhuis, 145-165. Leiden: Brill, 2006.

Millard, A. The Eponyms of the Assyrian Empire 910-612 BC. Helsinki: Neo-Assyrian Text Corpus Project, 1994.

Millard, A. "Observations from the Eponym lists." In Assyria 1995, edited by S. Parpola and R. Whiting, 207-215. Helsinki: Neo-Assyrian Text Corpus Project, 1997.

Möller, A. “Der Stammbaum der Philaiden. Über Funktion der Genealogie bei den Griechen.” In Retrospektive, edited by M. Flashar, H.-J. Gehrke and E. Heinrich, 17-35. Munich: Biering \& Brinkmann, 1996.

Möller, A. “The beginning of chronography: Hellanicus' hiereiai." In The Historian's Craft in the Age of Herodotus, edited by N. Luraghi, 241-262. Oxford: Oxford U. P., 2001.

Möller, A. “Elis, Olympia und das Jahr 580 v.Chr. Zur Frage der Eroberung der Pisatis." In Rollinger and Ulf 2004, 245-266. 2004 a.

Möller A. "Greek chronographic traditions about the first Olympic games." In Time and Temporality in the Ancient World, edited by R. Rosen, 169-184. Philadelphia: University of Pennsylvania, 2004b.

Möller, A. "Epoch-making Eratosthenes." GRBS 45 (2005): 245-260.

Möller, A. "Felix Jacoby and ancient Greek chronography." In Aspetti dell'opera di Felix Jacoby, edited by C. Ampolo, 259-275. Pisa: Edizioni della Normale, 2006.

Montanari F. “Apollodoros.” In Der Neue Pauly 1, edited by H. Cancik, 857-860. Stuttgart: Metzler, 1996. 
Mosshammer, A. The Chronicle of Eusebius and Greek Chronographic Tradition. London: Associated University, 1979.

Novotny, J. "Temple building in Assyria: evidence from royal inscriptions." In From the Foundations to the Crenellations, edited by M. Boda and J. Novotny, 109-140. Münster: Ugarit, 2010.

Panchenko, D. “Democritus' Trojan era and the foundation of early Greek chronology." Hyperboreus 6 (2000): 31-78.

Pearson, L. Early lonian Historians. Oxford: Clarendon, 1939.

Pfeiffer, R. History of Classical Scholarship from the Beginnings to the End of the Hellenistic Age. Oxford: Clarendon, 1968.

Plommer, W. "The tyranny of the archon list." CR 19 (1969): 126-129.

Ponchia S. "Describing the empire: some notes on Tiglath-pileser III's inscriptions." SAAB 22 (2016): 1-38.

Porciani, L. “Il problema della storia locale." In Aspetti dell'opera di Felix Jacoby, edited by C. Ampolo, 173-184. Pisa: Edizioni della Normale, 2006.

Pritchett, W. Greek Archives, Cults, and Topography. Amsterdam: Gieben, 1996.

Pruzsinszky, R. "Zum Verständnis der assyrischen Distanzangaben: Beiträge zur assyrischen Chronologie." SAAB 14 (2002-5): 23-31.

Pruzsinszky, R. "Šamši-Adads I. 'Neue' Regierungsdaten und assyrische Distanzangaben.” In Timelines, edited by E. Czertny, et al., 73-79. Leuven: Peeters, 2006.

Raaflaub, K. "Das frühe politische Denken der Griechen im interkulturellen Zusammenhang des Mittelmeerraumes." In Der Orient und die Anfänge Europas, edited by M. Hartmut, N. Oettinger and S. Schröder, 241-266. Wiesbaden: Harrassowitz, 2011.

Rathmann, M. Diodor und seine Bibliotheke. Berlin: De Gruyter, 2016.

Rhodes, P. A Commentary on the Aristotelian Athenaion Politeia. Oxford: Clarendon, 1981. Rhodes, P. Atthis. Heidelberg: Antike, 2014.

Rollinger, R. "Die Verschriftlichung von Normen: einflüsse und Elemente orientalischer Kulturtechnik in den homerischen Epen, dargestellt am Beispiel des Vertragswesens." In Rollinger and Ulf 2004, 369-425.

Rollinger, R. "Dareios und Xerxes an den Rändern der Welt und die Inszenierung von Weltherrschaft - Altorientalisches bei Herodot." In Herodots Quellen - Die Quellen des Herodot, edited by B. Dunsch and K. Ruffing, 95-116. Wiesbaden: Harrassowitz, 2013.

Rollinger, R. "Homer and the Ancient Near East. Some considerations on intercultural affairs." In Case Studies in Transmission, edited by I. Lindstedt, et al., 131-142. Münster: Ugarit, 2014a.

Rollinger, R. "Thinking and writing about history in Teispid and Achaemenid Persia." In Thinking, Recording, and Writing History in the Ancient World, edited by K. Raaflaub, 187-212. Chichester: Wiley-Blackwell, 2014b.

Rollinger, R. "Megasthenes, mental maps and Seleucid royal ideology: the western fringes of the world or how Ancient Near Eastern empires conceptualized world dominion." In Megasthenes und seine Zeit, edited by J. Wiesehöfer, H. Brinkhaus and R. Bichler, 129-164. Wiesbaden: Harrassowitz, 2016.

Rollinger, R. "Altorientalisches bei Herodot: das wiehernde Pferd des Dareios I." In Zwischen Assur und Athen, edited by H. Klinkott and N. Kramer, 13-42. Stuttgart: Steiner, 2017.

Rollinger, R. and K. Schnegg, editors. Kulturkontakte in antiken Welten. Leuven: Peeters, 2014.

Rollinger, R. and C. Ulf, editors. Griechische Archaik und der Orient. Berlin: De Gruyter, 2004. 
Rotstein, A. Literary History in the Parian Marble Cambridge, MA: Harvard U. P., 2016.

Rubio, G. "Scribal secrets and antiquarian nostalgia: tradition and scholarship in ancient Mesopotamia." In Reconstructing a Distant Past, edited by D. Barreyra Fracaroli and G. del Olmo Lete, 155-182. Barcelona: Editorial AUSA, 2009.

Ruschenbusch, E. "Was Hellanikos the first chronicler of Athens? Eine Antwort auf den gleichnamigen Artikel von Christopher Joyce." Klio 85 (2003): 7-8.

Ryan, F. “Die Herkunft der zu Kyrene ansässigen Periöken.” Libyan Studies 32 (2001): 79-85.

Said, E. Orientalism. New York: Vintage, 1978.

Samuel, A. Greek and Roman Chronology. Munich: Beck, 1972.

Schaudig, H. Die Inschriften Nabonids von Babylon und Kyros' des Großen samt den in ihrem Umfeld entstandenen Tendenzschriften. Münster: Ugarit, 2001.

Schaudig, H. "Nabonid, der ,Archäologe auf dem Königsthron'. Zum Geschichtsbild des ausgehenden neubabylonischen Reiches.” In Festschrift für Burkhart Kienast, edited by G. Selz, 447-497. Münster: Ugarit, 2003.

Schaudig, H. "The restoration of temples in the Neo- and Late Babylonian periods: a royal prerogative as the setting for political argument." In From the Foundations to the Crenellations, edited by M. Boda and J. Novotny, 141-164. Münster: Ugarit, 2010.

Schepens, G. “Die Debatte über die Struktur der „Fragmente der griechischen Historiker“.” Klio 92 (2010): 427-461.

Schmidtke, F. “Die Fehldatierung Naramsins durch Nabonid.” WO 1 (1947-52): 51-56.

Schwartz, E. "Die Königslisten des Eratosthenes und Kastor mit Excursen über die Interpolationen bei Africanus und Eusebius." Abhandlungen der philologisch-historischen Klasse der Königlichen Gesellschaft der Wissenschaften zu Göttingen 40 (1894): 1-96.

Shaw, P.-J. Discrepancies in Olympiad Dating and Chronological Problems of Archaic Peloponnesian History. Stuttgart: Steiner, 2003.

Sickinger, J. Public Records and Archives in Classical Athens, Chapel Hill: University of North Carolina, 1999.

Strasburger, H. “Herodots Zeitrechnung.” Hist. 5 (1956): 129-161.

Strothmann, M. and K.-W. Welwei. "X. 1 Archonten von Athen." In Herrscherchronologien der antiken Welt. Der Neue Pauly Suppl. 1, edited by W. Eder and J. Renger, 145-168. Stuttgart: Metzler, 2004.

Tadmor, H. "The campaigns of Sargon II of Assur: a chronological-historical study (conclusion)." JCS 12 (1958): 77-100.

Tadmor, H. "Propaganda, literature, historiography: cracking the code of the Assyrian royal inscriptions." In Assyria 1995, edited by S. Parpola and R. Whiting, 325-338. Helsinki: Neo-Assyrian Text Corpus Project, 1997.

Taylor, J. Framing the Past. PhD thesis, University of Michigan, 2000.

Thomas, R. Oral Tradition and Written Record in Classical Athens. Cambridge: Cambridge U. P., 1989.

Toye, D. "Dionysius of Halicarnassus on the first Greek Historians.” AJPh 116 (1995): 279-302.

Ulf, C. "Rethinking cultural contact." In Rollinger and Schnegg 2014, 507-564. 2014a.

Ulf, C. "Eine Typologie von kulturellen Kontaktzonen - oder: rethinking cultural contacts auf dem Prüfstand." In Rollinger and Schnegg 2014, 469-504. 2014 b.

Unz, R. "The chronology of the Elean War." GRBS 27 (1986): 29-42.

Van de Mieroop, M. "The Mesopotamians and their past." In Periodisierung und Epochenbewusstsein im Alten Testament und in seinem Umfeld, edited by T. Krüger and J. Wiesehöfer, 37-56. Stuttgart: Steiner, 2012. 
Van Dongen, E. “The concept of 'the Near East': a reconsideration.” In Rollinger and Schnegg 2014, 253-267.

Wachsmuth, C. Commentatio Vernaculo Sermone Conscripta de Eratosthene, Apollodoro, Sosibio Chronographis. Leipzig: Edelmann, 1892.

Wachsmuth C. Einleitung in das Studium der Alten Geschichte. Leipzig: Hirzel, 1895.

Waerzeggers, C. "The Babylonian chronicles: classification and provenance.” JNES 71 (2012): 285-298.

Waerzeggers, C. "Facts, propaganda, or history? Shaping political memory in the Nabonidus Chronicle." In Political Memory in and after the Persian Empire, edited by J. Silverman and C. Waerzeggers, 95-124. Atlanta: Society of Biblical Literature, 2015.

Waerzeggers, C. “Manuscript and archive. Who wrote and read Babylonian chronicles?" In Fink and Rollinger 2018, 335-346.

Weißbach, F. “Aššurahiddin.” In Reallexikon der Assyriologie und vorderasiatischen Archäologie 1, edited by E. Ebeling and E. Weidner, 198-203. Berlin: De Gruyter, 1928.

Weissert, E. "Interrelated chronographic patterns in the Assyrian eponym chronicle and the ,Babylonian Chronicle‘. A comparative view." In La Circulation des biens, des personnes et des idées dans le Proche-Orient ancien, edited by D. Charpin and F. Joannès, 273-282. Paris: Éditions Recherche sur les Civilisations, 1992.

Welwei, K.-W. Die griechische Polis. 3rd ed. Stuttgart: Steiner, 2017.

West, M. The East Face of Helicon. Oxford: Clarendon, 1997.

West, M. “Gilgāmeš and Homer: the missing link?" In Wandering Myths, edited by L. AudleyMiller and B. Dignas, 265-280. Berlin: De Gruyter, 2018.

Westbrook, R. Ex Oriente Lex. Ed. by D. Lyons and K. Raaflaub. Baltimore: Johns Hopkins U. P., 2015.

Will, W. "Einleitung." In Diodoros, edited by 0. Veh and W. Will, 1-16. Stuttgart: Hiersemann, 1998.

Yamada, S. "Neo-Assyrian eponym lists and eponym chronicles: stylistic variants and their historical-ideological background." In Fink and Rollinger 2018, 75-96.

Zaia, S. "How to (not) be king: negotiating the limits of power within the Assyrian hierarchy." JNES 77 (2018): 207-217.

Zanker, P. Augustus und die Macht der Bilder. Leipzig: Koehler \& Amelang, 1987.

Zawadzki, S. The Fall of Assyria and Median-Babylonian Relations in Light of the Nabopolassar Chronicle. Poznań: Adam Mickiewicz U. P., 1988a.

Zawadzki, S. "Umman-Manda: Bedeutung des Terminus und Gründe seiner Anwendung in der Chronik des Nabopolassar." In Šulmu, edited by P. Vavroušek and V. Souiek, 379-387. Prague: Charles University Prague, 1988b. 